\title{
Iodine speciation and size distribution in ambient aerosols at a coastal new particle formation hotspot in China
}

\author{
Huan Yu ${ }^{1,2}$, Lili Ren ${ }^{2}$, Xiangpeng Huang ${ }^{2}$, Mingjie $\mathrm{Xie}^{2}$, Jun $\mathrm{He}^{3}$, and Hang Xiao ${ }^{4}$ \\ ${ }^{1}$ Department of Atmospheric Science, School of Environmental Studies, \\ China University of Geosciences, Wuhan 430074, China \\ ${ }^{2}$ School of Environmental Science and Engineering, Nanjing University of Information Science and Technology, \\ Nanjing 210044, China \\ ${ }^{3}$ Department of Chemical and Environmental Engineering, University of Nottingham Ningbo China, Ningbo 315100 , China \\ ${ }^{4}$ Ningbo Urban Environment Observation and Research Station, Institute of Urban Environment, \\ Chinese Academy of Sciences, Xiamen 361021, China
}

Correspondence: Huan Yu (yuhuan_1981@163.com)

Received: 27 December 2018 - Discussion started: 4 January 2019

Revised: 21 March 2019 - Accepted: 22 March 2019 - Published: 29 March 2019

\begin{abstract}
Intense new particle formation (NPF) events were observed in the coastal atmosphere during algae growth and farming season at Xiangshan gulf of the east China coast. High nucleation-mode iodine concentrations measured by ultra-performance liquid chromatography coupled with quadrupole time-of-flight mass spectrometry (UPLC/QTOF-MS) confirmed that the NPF events were induced by iodine species. Our study provides important information on iodine speciation, size distributions, and its role in NPF in the context of heavy air pollution in China's coastal areas. For the first time, we identified 5 inorganic iodine species, 45 organic iodine compounds (35 molecular formulas), and a group of iodide-organic adducts in aerosols. The concentrations and size distributions of iodine species down to $10 \mathrm{~nm}$ were measured during the iodine-induced NPF, continental NPF, and non-NPF days at the coastal site and compared to those at an inland site. The iodine in the above four aerosol sample types were characterized by iodate, aromatic iodine compounds, iodoacetic acid or iodopropenoic acid, and iodide-organic adducts, respectively. Iodide and organic iodine compounds were found in the nucleation-mode particles; however, it is still not clear whether they contributed to nucleation or just new particle growth. Wild algae, as well as farmed algae, could be an important NPF source in China's coastal areas.
\end{abstract}

\section{Introduction}

Iodine is an essential trace element for all mammals (including human beings) and some aquatic plants. The atmospheric impact of iodine includes ozone $\left(\mathrm{O}_{3}\right)$ depletion, altering $\mathrm{HO}_{x}$ and $\mathrm{NO}_{x}$ chemistry, mercury oxidation, and aerosol formation (Baker et al., 2001; O’Dowd et al., 2002a). Marine emission sources of iodine-containing species in the atmospheresuch as iodomethane, molecular iodine $\left(\mathrm{I}_{2}\right)$, and hypoiodous acid (HOI) - include marine biota emission (Baker et al., 2000), sea surface iodide $\left(\mathrm{I}^{-}\right)$activation by $\mathrm{O}_{3}$ (Dixneuf et al., 2009; Mcfiggans et al., 2004; Palmer et al., 2005; Sellegri et al., 2006), and sea surface bubble bursting (Seto and Duce, 1972). Continental iodine sources include soil emission, fossil fuel and biomass combustions, and industrial emissions (Redeker et al., 2000; Sive et al., 2007). In recent years, much attention has been paid to the new particle formation (NPF) induced by iodine species (Kumar et al., 2018; Dall'Osto et al., 2018; Allan et al., 2015; Roscoe et al., 2015; Mahajan et al., 2011; McFiggans et al., 2010; O’Dowd and De Leeuw, 2007; Grose et al., 2007; Yoon et al., 2006; O'Dowd et al., 2002b). Based on current knowledge, a simplified scheme of iodine oxidation and nucleation is described as follows: volatile iodocarbons or $\mathrm{I}_{2}$ photolyze to I atoms, which react with $\mathrm{O}_{3}$ to produce $\mathrm{IO}$ and $\mathrm{IO}_{2}$ radicals; subsequently, the self-combination of $\mathrm{IO}$ and $\mathrm{IO}_{2}$ forms iodine oxides $\mathrm{I}_{2} \mathrm{O}_{2-5}$; iodine oxoacids $\mathrm{HIO}_{\mathrm{x}}(x=1-3)$ are produced either from $\mathrm{I}_{2} \mathrm{O}_{2-5}$ hydration or via the reaction of $\mathrm{IO}$ and $\mathrm{IO}_{2}$ with $\mathrm{HO}_{x}$ 
(Burkholder et al., 2004; Martín et al., 2013; Sipilä et al., 2016); eventually, the clustering of $\mathrm{I}_{2} \mathrm{O}_{2-5}$ (or $\mathrm{HIO}_{\mathrm{x}}$ ) and the subsequent growth of these iodine particles in the presence of other condensable vapors contribute to cloud condensation nuclei $(\mathrm{CCN})$ so as to influence the climate.

In the past, iodine concentration or speciation had been measured in natural water and drinking water (Chen et al., 2007; Liu et al., 2015; Wang and Jiang, 2008; Wei et al., 2007), precipitation (Gilfedder et al., 2007a; Yoshida et al., 2007), soil (Yoshida et al., 2007), animal and macroalgae tissues (Hughes et al., 2006; Kaňa et al., 2015; Shah et al., 2005), edible salts (Yun et al., 2017; Zhang et al., 2010), and milk (Wang and Jiang, 2008). Previous measurements in ambient aerosols showed only three iodine species: $\mathrm{I}^{-}$, iodate $\left(\mathrm{IO}_{3}^{-}\right)$, and total soluble organic iodine (SOI) and their relative concentration and size distribution varied largely with location (e.g., inland, coastal, or open ocean; Baker et al., 2001; Gilfedder et al., 2007a, b; Lai et al., 2008; Wimschneider and Heumann, 1995; Xu et al., 2010). The majority of atmospheric models assume that $\mathrm{IO}_{3}^{-}$would be the only stable and predominant iodine species in aerosols (SaizLopez et al., 2012), because $\mathrm{I}^{-}$may be eventually oxidized to $\mathrm{IO}_{3}^{-}$in aerosols or participate in halogen activation to yield gaseous I $X(X=\mathrm{Cl}, \mathrm{Br}, \mathrm{I})$. SOI deems to be formed from the reaction of aerosol organic matter with HOI (Baker, 2005). Organic iodine compounds are more toxic than $\mathrm{I}^{-}$and $\mathrm{IO}_{3}^{-}$ to humans (Ding and Zhang, 2009) and may play a key role in regulating the recycling of halogens to the gas phase. At present the speciation of organic iodine compounds is the most significant knowledge gap in aerosol iodine chemistry (Saiz-Lopez et al., 2012). Hence, to study the iodine speciation and size distribution will surely help to understand their sources, transformation mechanisms, and deposition rates in the atmosphere.

It still poses a challenge to determine organic iodine compounds in ambient aerosol. Up to date, there is no detailed aerosol organic iodine speciation study in the literature. Total SOI was generally calculated as total soluble iodine minus inorganic $\mathrm{I}^{-}$and $\mathrm{IO}_{3}^{-}$(Lai et al., 2008), which can be separated and quantified using an ion chromatography coupled with inductively coupled plasma mass spectrometry (IC-ICP$\mathrm{MS})$. Although the peaks in IC other than $\mathrm{I}^{-}$and $\mathrm{IO}_{3}^{-}$were suspected to be organic iodine (Gilfedder et al., 2007a, b, 2008), ICP-MS did not provide molecular weight information. Without foreknown information of ion mass, molecular structure, or retention time (RT), neither liquid chromatography MS (LC-MS) nor gas chromatography MS (GC-MS) can be applied to identify and quantify unknown organic iodine in the aerosols. Unlike those in disinfection by-products or iodine-rich seaweed, an individual organic iodine compound in a complex aerosol matrix is of extremely low concentration. Based on our experience, organic iodine ions co-elute with many other interfering ions even after chromatographic separation. As a result, it is difficult to apply even highresolution mass spectrometry to identify unknown organic iodine compounds in the aerosols using MS and MSMS techniques.

The populated coastal regions of eastern China are influenced by both industrial and marine emissions. Increasing algae populations due to serious eutrophication in the coastal waters may promote iodine emission, which makes the coastal region a potential hotspot of new particle formation. Up to now, there has been no report of iodineinduced NPF in places other than coastal sites of western Europe (e.g., Mace Head, Ireland; Roscoff, France; O Grove, Spain), Tasmania (Cape Grim), and polar regions. Besides, the iodine speciation measurement in particles smaller than $100 \mathrm{~nm}$ is also scarce (Baker, 2004, 2005a; Gilfedder et al., 2008; Lai et al., 2008; Wimschneider and Heumann, 1995). The purpose of our study is to characterize iodine speciation using the ultra-performance liquid chromatography coupled with quadrupole time-of-flight mass spectrometry (UPLC/Q-TOF-MS) and measure their concentrations in size-segregated particles down to $10 \mathrm{~nm}$ diameter collected during the NPF events observed at a coastal site of China. The comparison of iodine species between the coastal site and an inland site will also be discussed.

\section{Experiments}

\subsection{Sampling}

A 5-month campaign from January to May 2018 was carried out at Xiangshan gulf of Zhejiang Province on the east coast of China. The coastal observation site $\left(29^{\circ} 29^{\prime} \mathrm{N}, 121^{\circ} 46^{\prime} \mathrm{E}\right.$; see Fig. 1) is a small building about 40 and $200 \mathrm{~m}$ away from the coastline at high tide and low tide, respectively. The $\mathrm{Xi}$ angshan gulf is developed as the largest algae cultivation area of Zhejiang Province. This feature makes the Xiangshan gulf a potential hotspot of iodine emission from wild or farmed algae. We used a scanning mobility particle spectrometer (SMPS) and a neutral air ion spectrometer (NAIS) to monitor NPF events at the site. The statistical characteristics of new particle formation at the observation site are not the focus of this paper. Instead, a nano-microorifice uniform deposit impactor (nano-MOUDI; MSP Corp, Shoreview, MN) or a median-volume aerosol sampler were used to collect size-segregated $10 \mathrm{~nm}-18 \mu \mathrm{m}$ aerosols or $\mathrm{PM}_{2.5}$ during typical NPF days. The 13-stage nano-MOUDI provides $d_{50}$ cut-off sizes of $18,10,5.6,3.2,1.8,1.0,0.56,0.32,0.18$, $0.10,0.056,0.032,0.018$, and $0.010 \mu \mathrm{m}$ in aerodynamic diameters when operating at a flow rate of $30 \mathrm{~L} \mathrm{~min}^{-1}$. The offline method by using a high-resolution mass spectrometer was developed to analyze iodine in the aerosol samples.

A particle size distribution from 2 to $740 \mathrm{~nm}$ was obtained by integrating a long SMPS (TSI DMA3081 and CPC3775; scanning range: $40-750 \mathrm{~nm}$ ) and NAIS (scanning range: $2-$ $42 \mathrm{~nm}$ ) data. The SMPS sampled ambient air from a $129 \mathrm{~cm}$ long and $1.0 \mathrm{~cm}$ inner diameter (I.D.) stainless steel tube hor- 


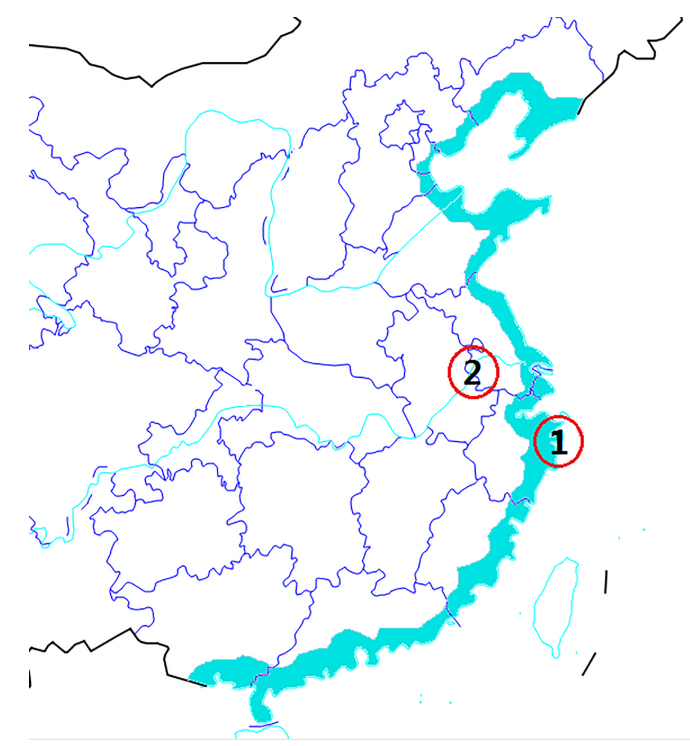

Figure 1. Locations of two sampling sites: (1) the coastal site at Xiangshan gulf and (2) the inland urban site that is $200 \mathrm{~km}$ from the coast. The blue color indicates the coastal area of the Chinese mainland.

izontally oriented with an airflow of $14 \mathrm{~L} \mathrm{~min}^{-1}$ (standard liter per minute). The NAIS sampling inlet was a $150 \mathrm{~cm}$ long and $32 \mathrm{~cm}$ I.D. copper tube. The transport loss of particles in the SMPS and NAIS inlets was corrected using sizedependent survival ratios. Scanning cycles of the SMPS and NAIS were synchronized to $4 \mathrm{~min}$. The NAIS measured positive ion, negative ion, and total particles alternately. The classification of iodine-induced NPF (hereafter, I-NPF event) and continental NPF events was based on the size distribution observation and described in Sect. 3.1.

A nano-MOUDI sampling scheme was implemented according to the NPF classification. That is, one set of nanoMOUDI samples was collected during the continental NPF days from 11 to 13 February; a second set of nano-MOUDI samples was collected during the non-NPF days from 16 to 18 April; a third set of nano-MOUDI samples was collected during the I-NPF days from 9 to 11 May, and three sets of daily $\mathrm{PM}_{2.5}$ samples were collected during the I-NPF days from 25 to 27 April. Each set of nano-MOUDI samples was collected continuously for $72 \mathrm{~h}$, during which I-NPF or continental NPF occurred on a daily basis, so aerosol chemical composition features of these two types of NPF events can be observed from offline analysis. In addition, as a comparison to the coastal site, four sets of $\mathrm{PM}_{2.5}$ samples were randomly collected on 14 January, 15 April, 25 April, and 5 May at an inland urban site $200 \mathrm{~km}$ from the coast (see Fig. 1). The description of the inland site can be found in Yu et al. (2016). No simultaneous measurement of particle size distribution was made at the inland site.
The detailed sampling procedures for $\mathrm{PM}_{2.5}$ and nanoMOUDI are as follows. $\mathrm{PM}_{2.5}$ aerosols were collected on $90 \mathrm{~mm}$ quartz fiber filters using a median-volume aerosol sampler (TH-150C; Wuhan Tianhong Ltd., China) at a flow rate of $100 \mathrm{~L} \mathrm{~min}^{-1}$ for $23 \mathrm{~h}$. Since quartz fiber filters may absorb volatile iodine species like hydrogen iodide (HI), which introduces a positive artifact to $\mathrm{I}^{-}$measurements in aerosols, field blank filters were collected by placing a HEPA (highefficiency particulate air) filter in the upper stream of a quartz fiber filter. Two nano-MOUDIs were placed side by side to separately collect $10-100 \mathrm{~nm}$ (stages $10-13$ ) and $100 \mathrm{~nm}-$ $18 \mu \mathrm{m}$ (stages 1-9) aerosols. Considering low aerosol mass loading at stages 10-13, the chemical analysis of aerosols collected at stages 10-13 may be sensitive to the particle collisions from upper stages 1-9, Therefore, aluminum foil filters at stages 1-9 of the first nano-MOUDI were silicongreased to reduce potential collision artifacts on the filters of stages 10-13 that were sent for chemical analysis. For the second nano-MOUDI, all filters were not silicon-greased but only the filters of stages 1-9 were sent for chemical analysis. One set of field blank nano-MOUDI samples was also collected by drawing the air through the nano-MOUDI with a HEPA filter attached to the inlet. Before sampling, the filters were baked in a laboratory oven at ca. $500^{\circ} \mathrm{C}$ for $24 \mathrm{~h}$ to remove organics. After sampling, the filters were packed and stored in a freezer below $-20^{\circ} \mathrm{C}$.

\subsection{Chemical analysis}

A quarter or half of a filter was put in a $10 \mathrm{~mL}$ amber vial with $1: 1 \mathrm{v} / \mathrm{v}$ mixture of water (LCMS grade, Aladdin, China) and methanol (LCMS grade, Adamas, China). The filter fraction was sonicated for $40 \mathrm{~min}$ and the extract was filtered by a $0.2 \mu \mathrm{m}$ PTFE membrane syringe filter. The eluate was evaporated to almost dryness in a rotary evaporator below $40^{\circ} \mathrm{C}$ and subsequently redissolved in $0.5 \mathrm{~mL}$ water. After being centrifuged (12000 rpm) for $30 \mathrm{~min}$, the supernatant was collected for MS analysis using a Waters UPLC (BEH column, $1.7 \mu \mathrm{m}$ column, $2.1 \mathrm{~mm} \times$ $50 \mathrm{~mm}$ ) coupled with a Xevo G2 Q-TOF-MS. A gradient eluent at a flow rate of $4 \mathrm{~mL} \mathrm{~min}^{-1}$ was applied as below: $2 / 98$ methanol / water for $0.5 \mathrm{~min}$, linearly increased to $98 / 2$ over $9.5 \mathrm{~min}, 98 / 2$ held for $2 \mathrm{~min}$, and returned to $2 / 98$ for $3 \mathrm{~min}$. The MS was operated in either positive or negative mode with a TOF resolving power of $32000 \mathrm{FWHM}(\mathrm{ESI}+)$ or 28000 FWHM (ESI-). The MS was externally calibrated daily in the mass range $50-1200 \mathrm{Da}$ using a $0.5 \mathrm{mM}$ sodium formate solution. A real-time lock-mass correction was applied by acquiring a leucine-enkephalin spectrum from a lock spray source. Optimized source parameters were as follows: capillary voltage $-2.5 \mathrm{kV}$ for $\mathrm{ESI}-$ (or $+3.0 \mathrm{kV}$ for ESI+), desolvation gas flow $600 \mathrm{~L} \mathrm{~h}^{-1}$ with temperature $450^{\circ} \mathrm{C}$ and source temperature $120^{\circ} \mathrm{C}$. Depending on the purpose, the Q-TOF-MS was operated in three modes: lowenergy MS scan mode (in which molecular ions are subject 
to in-source fragmentation only), high-energy MS scan mode (in which molecular ions are subject to both in-source fragmentation and collision-induced dissociation) and MSMS mode (in which selected precursor ions are subject to fragmentation with collision-induced dissociation before entering the TOF cell). Collision cell voltage was scanned from 10 to $40 \mathrm{eV}$. The mass spectrum was acquired as continuum format and analyzed by the MassLynx 4.1 software. The procedure of identification and semi-quantification of iodine species will be explained in detail in Sect. 3. To validate the semi-quantification by our procedure, 20 samples with relatively high iodine concentration were also analyzed for total soluble iodine using Agilent 7500a ICP-MS (Agilent Technologies, Santa Clara, CA, USA). To do that, $200 \mu \mathrm{L}$ aerosol extract was diluted to $5 \mathrm{~mL}$ for injection and the iodine detection limit of the ICP-MS was $0.1 \mu \mathrm{g} \mathrm{L}-1$.

\section{Results and discussion}

Section 3.1 first discusses particle number size distribution patterns of two types of NPF events at the coastal site. Section 3.2 discusses the identification and semi-quantification of iodine species in the ambient aerosols. The speciation and size distribution of iodine species during the two types of NPF events at the coastal site are shown in Sect. 3.3. The comparison of iodine species between the coastal site and the inland site is discussed in Sect. 3.4.

\subsection{Particle number size distribution patterns of iodine-induced NPF and continental NPF events}

Based on the particle size distribution data, we identified two types of NPF events. The first type of NPF event was observed on 7 out of 54 non-raining observation days during the cold season from January to March. Figure 2a shows the typical particle number size distributions of this type of NPF event from 11 to 13 February. As we can see in Fig. 2a, the production of $2-7 \mathrm{~nm}$ neutral particles began at 08:0009:00 LT (local time) and ceased at around 15:00 LT. New particle formation appeared to be not associated with the low tide, but followed a nearly identical variation with both solar radiation and daytime tide height. After the formation, new particles grew to about $100-200 \mathrm{~nm}$ in the middle of the night, following a typical banana-shape contour (Fig. 2a, 1st row). These features, together with the air mass backward trajectories originating from the northwest inland(Fig. S2), confirm that this was a regional-scale continental NPF event. Air mass backward trajectories were computed using the HYSPLIT (Hybrid Single-Particle Lagrangian Trajectory, NOAA/ARL) model (Draxler and Rolph, 2003). $N_{2-20}$, number concentration of $2-20 \mathrm{~nm}$ particles, reached up to $7 \times 10^{4}-1.3 \times 10^{5} \mathrm{~cm}^{-3}$ during this type of NPF event, which is higher than the average $N_{3-20}$ of $2.5 \times 10^{4} \mathrm{~cm}^{-3}$ during the continental NPF events recorded by us at Nanjing, on inland urban site in 2016 (Dai et al., 2017).

Strong NPF events were observed on 24 out of 33 nonraining observation days in April and May, which is the growth and farming season of seaweed. That is, the second type of NPF events occurred almost every day from April to May unless it was cloudy or rainy. As discussed in Sect. 3.3, high nucleation-mode iodine concentrations suggest these NPF events were induced by iodine. Figure $2 b$ shows the typical particle number size distributions from 8 to 10 May. As can be seen, the production of 2-7 nm particles began at 09:00-10:00 LT and lasted until 18:00 LT. There is a clear time lag of $\sim 4 \mathrm{~h}$ between solar radiation increase and the production of 2-7 nm particles. High $N_{2-7}$ (number concentration of 2-7 nm particles) seemed to be associated with low tide during 13:00-15:00 LT. $N_{2-20}$ reached up to $7 \times 10^{6}-1 \times 10^{7} \mathrm{~cm}^{-3}$, which is 2 orders of magnitude higher than those during the continental NPF. The peak $N_{2-20}$ values at this coastal site are also 1 order of magnitude higher than those recorded during the most intense I-NPF events at Mace Head, Ireland $\left(5 \times 10^{5}-1 \times 10^{6} \mathrm{~cm}^{-3}\right.$; O'Dowd et al., 2002a). A clear nucleation mode below $30 \mathrm{~nm}$ was seen on each sampling day and particles rarely grew beyond $30 \mathrm{~nm}$ at the coastal site of our study. The "interrupted" growth pattern suggested that the NPF was limited in a relatively small area around the site. Wild and farmed algae at the Xiangshan gulf were likely the source of these high concentration nucleation-mode particles. In particular, during the harvesting season, the wet algae have to be dehydrated by exposing them to sunlight for a few days before further processing or transportation. During this process, a large amount of iodine vapors can be emitted and oxidized to produce new particles.

It has been reported from both field and laboratory studies that I-NPF is initiated by a pure negative ion nucleation of $\mathrm{HIO}_{3}$ (Sipilä et al., 2016). We examined neutral, positive, and negative nanoparticle concentrations measured by NAIS during the two types of events. It has been found that during the I-NPF events, the negative ion concentrations were $100 \pm 102 \%, 8 \pm 13 \%$, and $58 \pm 32 \%$ higher than those of positive ions in the size ranges of $0.8-2,2-7$, and $7-20 \mathrm{~nm}$, respectively. On the other hand, negative and positive ion concentrations in all abovementioned size ranges were almost the same during the continental NPF events (Fig. 2a, row 4-6). The neutral particle concentrations during I-NPF events were higher than those in continental NPF events by two orders of magnitude; however, the ion concentrations were similar in both types of NPF events, which were in the concentration range of $100-1000 \mathrm{~cm}^{-3}$ in all size bins. As a result, the ratios of ion concentration to neutral particle concentration were on the order of $10^{-5}(2-7 \mathrm{~nm})$ and $10^{-4}(7-20 \mathrm{~nm})$ during the I-NPF events and $10^{-3}(2-7 \mathrm{~nm})$ and $10^{-2}(7-20 \mathrm{~nm})$ during the continental NPF events, indicating the contribution of ions to total particles was negligible at least in $>2 \mathrm{~nm}$ size range in both types of NPF events. 


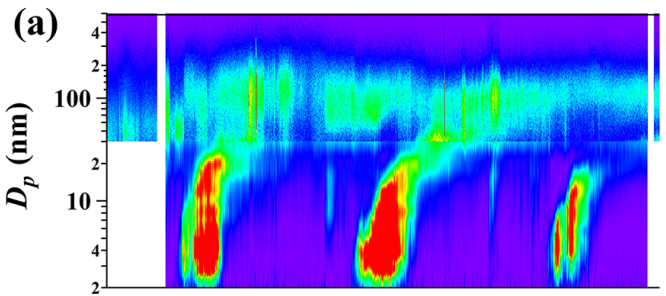

(b)
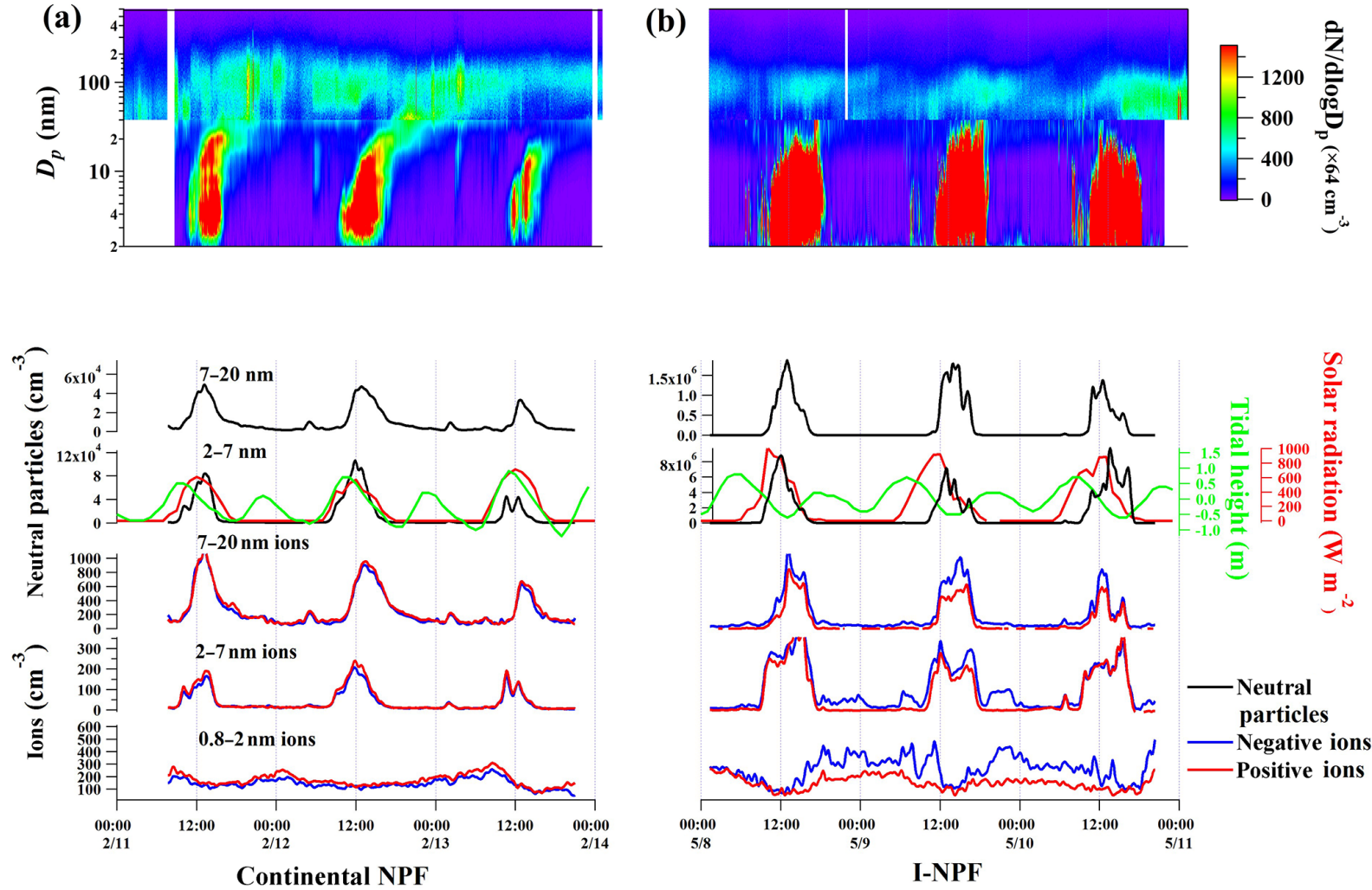

Figure 2. Particle number concentration during (a) the continental NPF days from 11 to 13 February 2018 and (b) the iodine-induced NPF (INPF) days from 8 to 11 May 2018. From top to bottom curves: particle size spectra of the NPF events; diurnal variations of 7-20 and 2-7 nm neutral particles (black curves); diurnal variations of 7-20, 2-7, and 0.8-2 nm negative (blue curves) and positive ions (red curves). Solar radiation and tidal height were obtained from local maritime authority and plotted as red and green curves, respectively.

\subsection{Iodine speciation and semi-quantification}

The high-resolution LC-MS offers the prospect of identifying unknown organic compounds in complex samples. Previous studies identified unknown organic iodine compounds in disinfected drinking water and seaweed based on the fact that the retention time and accurate mass of iodine-containing precursor ions can be selectively determined by searching their product ion $\mathrm{I}^{-}(m / z$ 126.9) in MSMS experiments (Ding and Zhang, 2009; Yang et al., 2016). Unfortunately, their strategy does not work for our aerosol samples because of two difficulties. First, we found that most iodinecontaining ions in our samples were dissociated to release $\mathrm{I}^{-}$ due to in-source fragmentation even in the most gentle ionization condition (e.g., low capillary voltage, low source and desolvation temperatures). This can been seen from Fig. 3a; extracted ion chromatograms of $m / z 126.9039$ are of similar intensity in low-energy MS scan mode (in-source fragmentation only) and high-energy MS scan mode (in-source fragmentation plus collision-induced dissociation). In this situation, it is impossible to select unfragmented iodinecontaining precursor ions for MSMS experiments. Second, even if organic iodine compounds can survive from in-source fragmentation, there are many co-eluting background interfering ions. It is time and labor consuming to search $\mathrm{I}^{-}$from all co-eluting molecular ions using MSMS experiments. This often becomes impractical because small organic iodine ions and other neighboring ions often appear in the same precursor isolation window of the quadrupole.

\subsection{1 iodide-organic adducts}

For reversed-phase liquid chromatography, ionic compounds elute earliest followed by non-ionic organics with longer retention times. In our case, ionic $\mathrm{I}^{-}, \mathrm{IO}_{x}^{-}$, and other strong Lewis acids elute with $\mathrm{RT}<1 \mathrm{~min}$, as can be seen from the extracted $m / z 126.9039$ chromatogram of pure potassium iodide solution $\left(1 \mathrm{mmol} \mathrm{L}^{-1}\right)$ in Fig. $3 \mathrm{~b}$. The $\mathrm{I}^{-}$peaks that eluted at RT $>1$ min in low-energy MS scan mode (Fig. 3a), on the other hand, can only be resulted from the dissociation of weakly bound iodine-containing organic precursors via in-source fragmentation. $\mathrm{I}^{-}$is an electronegative weak base, which can bind with hydroxyl, acid, or keto groups to form adducts depending upon the polarity and H-bonding capability of organic compounds (Lee et al., 2014). These iodine-containing organics that dissociated to release $\mathrm{I}^{-}$in the ESI source are thus attributed to iodide-organic adducts 


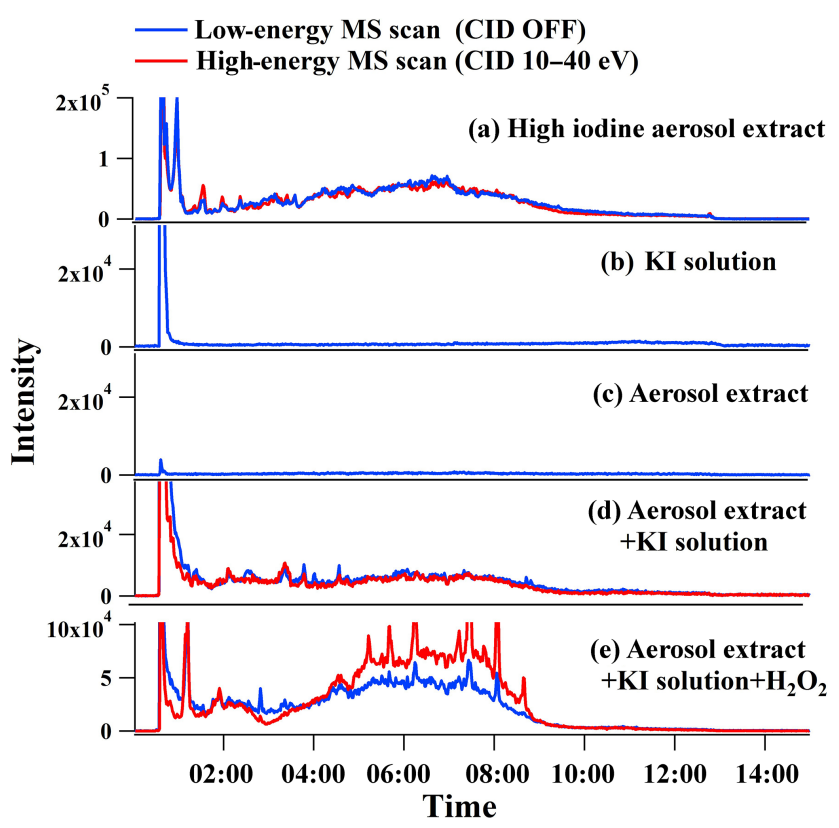

Figure 3. Ion chromatograms of $m / z \quad 126.9039$ of (a) aerosol extract with high concentration of iodine, (b) pure potassium iodide $(\mathrm{KI})$ solution $\left(1 \mathrm{mmol} \mathrm{L}^{-1}\right)$, (c) aerosol extract with low concentration of iodine, (d) the KI solution mixed with the aerosol extract with low concentration of iodine, and (e) the KI solution + aerosol extract mixture with the addition of $10 \mathrm{mmol} \mathrm{L}^{-1} \mathrm{H}_{2} \mathrm{O}_{2}$ solution. Blue curves: low-energy MS scan mode, in which collision-induced dissociation (CID) is off and molecular ions are subject to in-source fragmentation only. Red curves: high-energy MS scan mode, in which molecular ion are subject to both in-source fragmentation and $10-40 \mathrm{eV}$ collisioninduced dissociation.

in our study and the total peak area of extracted ion chromatogram of $m / z 126.9039$ after RT $1 \mathrm{~min}$ is assumed to be proportional to their total concentration. Our experiment presented in Fig. 3b-d partly supported the above hypothesis. No $\mathrm{I}^{-}$peak was detected after RT $1 \mathrm{~min}$ in the extracted $m / z 126.9039$ chromatograms of pure KI solution $\left(1 \mathrm{mmol} \mathrm{L}^{-1}\right.$, Fig. $\left.3 \mathrm{~b}\right)$ or an aerosol extract with low concentration of iodine (Fig. 3c). However, when the aerosol extract was mixed with KI solution for another analysis, elevated $\mathrm{I}^{-}$peaks in low-energy MS scan mode (blue line, Fig. 3d) indicated the formation of iodide-organic adducts. Furthermore, when collision-induced dissociation was applied, no additional $\mathrm{I}^{-}$peaks showed up in high-energy MS scan mode (red line, Fig. 3d). Such an observation implies that (1) iodide-organic adducts were formed in the aerosol extract + KI mixture but were easily dissociated in the lowenergy MS scan mode and (2) no stable organic iodine compounds were formed in the aerosol extract $+\mathrm{KI}$ mixture. This is also confirmed by the fact that no new ions were formed by comparing the mass spectra of aerosol extract before and after KI addition.

\subsubsection{Organic iodine compounds}

The identities of those stable organic iodine compounds, i.e., the compounds with $\mathrm{C}-\mathrm{I}$ bond that are not or partially dissociated in the ESI source, are still unknown but their atmospheric chemistry may be of more interest. To bypass the difficulty, as discussed above, a signal amplification approach has been applied in this study to identify these unknown organic iodine compounds, for which the detailed steps are shown in Fig. 4. The approach is analogous to searching a secondary organic aerosol (SOA) tracer in ambient aerosols after its identity as VOC oxidation product is confirmed by smog chamber simulations. A portion of low iodine aerosol extract $+\mathrm{KI}$ mixture was added with $\mathrm{H}_{2} \mathrm{O}_{2}$ solution $\left(10 \mathrm{mmol} \mathrm{L}^{-1}\right)$. After reaction for $4 \mathrm{~h}$, the mixture was injected for low- and high-energy MS scans. As compared to the chromatograms of the untreated mixture (Fig. 3d), a considerable amount of stable organic iodine compounds were formed but dissociated only in the high-energy MS scan (red curve in Fig. 3e), in addition to the formation of more iodideorganic adducts (low-energy MS scan, blue curve in Fig. 3e). These organic iodine compounds are believed to be from the reactions between aerosol organics and HOI that is produced via the $\mathrm{H}_{2} \mathrm{O}_{2}+\mathrm{I}^{-}$reaction.

The identities of these organic iodine compounds can be obtained by comparing MS scan mass spectra (low energy) before and after the $\mathrm{H}_{2} \mathrm{O}_{2}$ addition using a mass defect (MD) vs. $m / z$ diagram. The mass spectrum was reconstructed by integrating over RT $0-15 \mathrm{~min}$. All ions above background intensity of $10^{4}$ are shown in Fig. 5 as dots and circles to stand out for the samples before and after $\mathrm{H}_{2} \mathrm{O}_{2}$ addition, respectively. Benefiting from the large negative mass defect of iodine (-0.0961), the mass defects of newly formed organic iodine compounds should be in the range of $-0.3-0$, which distinguishes them easily from non-iodine-containing ions. Therefore, each red circle without a black dot in $-0.3-$ 0 mass defect range in Fig. 5 should stand for an organic iodine compound that was newly formed after the addition of $\mathrm{H}_{2} \mathrm{O}_{2}$ into the aerosol extract $+\mathrm{KI}$ mixture. These potential organic iodine ions were further selected for MSMS experiments to confirm that their fragments contained $\mathrm{I}^{-}$. Since mass assignment is more accurate for an amplified symmetrical peak than a small shoulder peak, the amplification of organic iodine compound concentrations helps to obtain accurate masses of potential iodine organic compounds in ambient aerosols. After that, their retention time information in the UPLC was acquired by extracting their ion chromatograms from low-energy MS scan data. Following the same procedure, two $\mathrm{PM}_{2.5}$ samples collected at the inland site and two $\mathrm{PM}_{2.5}$ samples collected at the coastal site were treated using $\mathrm{KI}$ and $\mathrm{H}_{2} \mathrm{O}_{2}$ (or $\mathrm{O}_{3}$ solution) and analyzed using MD vs. $m / z$ diagrams in both ESI+ and ESI- modes (step 1, Fig. 4).

In step 2, the elemental compositions of organic iodine compounds were calculated from the accurate masses within 


\begin{tabular}{|c|c|c|c|}
\hline \multicolumn{2}{|r|}{ Steps } & MS method & Data acquired \\
\hline 1 & $\begin{array}{l}\text { MD vs. } m / z \text { diagram comparison between } \\
\text { aerosol and aerosol }+\mathrm{KI}+\mathrm{H}_{2} \mathrm{O}_{2} / \mathrm{O}_{3}\end{array}$ & $\begin{array}{l}\text { Low-energy MS } \\
\text { scan }\end{array}$ & $\begin{array}{l}m / z \text { and RT of potential organic iodine } \\
\text { ions }\end{array}$ \\
\hline 2 & $\begin{array}{l}\text { Elemental composition calculation: } \\
\text { ChemSpider search }\end{array}$ & $\begin{array}{l}\text { MSMS } \\
\text { confirmation }\end{array}$ & $\begin{array}{l}80 \text { possible CHONSI chemical } \\
\text { formulas }\end{array}$ \\
\hline 3 & $\begin{array}{l}\text { Targeted screening in real aerosol } \\
\text { samples based on } \mathrm{m} / \mathrm{z} \text { and RT }\end{array}$ & $\begin{array}{l}\text { Low-energy MS } \\
\text { scan }\end{array}$ & $\begin{array}{l}35 \text { formulas ( } 47 \text { organic iodine } \\
\text { compounds) and their peak areas } \\
\text { observed in aerosol samples }\end{array}$ \\
\hline 4 & $\begin{array}{l}4 \text { compounds quantified with their } \\
\text { standards; } 43 \text { compounds semi-quantified } \\
\text { with surrogate standards }\end{array}$ & $\begin{array}{l}\text { Low-energy MS } \\
\text { scan of commercial } \\
\text { standards }\end{array}$ & $\begin{array}{l}\text { Concentrations of individual } \\
\text { non-aromatic compounds and total } \\
\text { aromatic iodine compounds }\end{array}$ \\
\hline
\end{tabular}

Figure 4. Identification and semi-quantification steps of unknown organic iodine compounds in ambient aerosols.

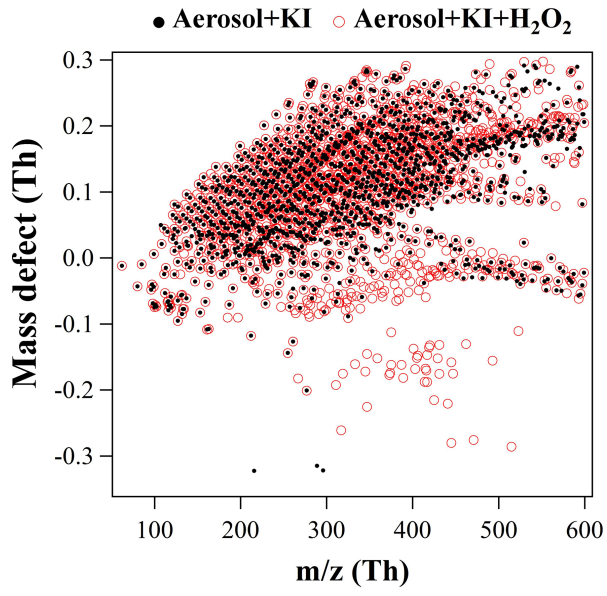

Figure 5. Mass defect (MD) vs. $m / z$ diagram of molecular ions before (black dots) and after (red circles) the addition of $\mathrm{H}_{2} \mathrm{O}_{2}$ into aerosol extract $+\mathrm{KI}$ mixture. The mass spectrum of all ions above background level $\left(10^{4}\right)$ was reconstructed by integrating over retention time $0-15 \mathrm{~min}$. Units (Th) are in thomson.

$1 \mathrm{mDa}$ mass tolerance allowing the elements $\mathrm{C}, \mathrm{H}, \mathrm{N}, \mathrm{O}$, $\mathrm{S}$ and I, and confirmed by their isotope patterns. The correctness of calculated molecular formulas was further restricted by the matching of at least one sound structure in the ChemSpider database. Consequently, a total of 80 formulas (57 in negative mode and 23 in positive mode) were obtained, each of which should represent an organic iodine compound and its isomers. Because both $\mathrm{H}_{2} \mathrm{O}_{2}$ and $\mathrm{O}_{3}$ are important oxidants in atmospheric aerosols, the organic iodine compounds formed in step 1 may also exist in real aerosol samples via the same reaction mechanism in the atmosphere. Therefore, in step 3 these newly identified 80 formulas were searched in real aerosol samples using a targeted screening strategy based on their accurate mass and retention time. At last, 35 organic iodine formulas were detected, at least once, in our aerosol samples including the $\mathrm{PM}_{2.5}$ sam- ples and the size-segregated aerosol samples from all nanoMOUDI stages (Table 1). The other formulas were not detected in any of the aerosol samples, probably due to their slower production rate or the absence of corresponding organic precursors in the atmosphere. The number of isomers listed in the second column of Table 1 is based on the number of ion chromatographic peaks observed for given $m / z$ values in the real aerosol samples. The 45 total isomer peaks, as well as their retention times, are shown in Fig. S1 in the Supplement. Hence, there are in total 45 organic iodine compounds detected in our samples.

As shown in Table 1, 35 molecular formulas were classified into four groups: 5 non-aromatic formulas with the rest being aromatic formulas including $16 \mathrm{CHOI}$ formulas, 3 CHNI formulas, and 11 CHONI formulas. The 5 non-aromatic formulas are assigned to iodoacetic acid, diiodoacetic acid, iodopropenoic acid, iodomethanesulfonic acid, and diiodomethane. The first four compounds are electrophilic substitution products of $\alpha-\mathrm{H}$ of organic acids by $\mathrm{I}^{+}$from HOI or $\mathrm{I}_{2}$. Diiodomethane is probably from gasparticle partitioning or the product of iodoform reaction of methyl ketones. Iodoacetic acid was identified in 9 of 10 samples collected from the coastal and inland sites. The other four non-aromatic compounds, however, were mostly found at the coastal site.

Thirty CHOI, CHONI, and CHNI formulas are assigned to aromatic compounds that are prone to electrophilic substitution by $\mathrm{I}^{+}$. The formulas observed in ESI- mode are expected to have a carboxyl or phenol group, while those observed in ESI+ mode should be aromatic or heterocyclic amines. Sixteen CHOI formulas are iodinated phenols, substituted benzoic acids, or phenolic acids. The three most frequently detected formulas are $\mathrm{C}_{8} \mathrm{H}_{7} \mathrm{O}_{2} \mathrm{I}, \mathrm{C}_{7} \mathrm{H}_{5} \mathrm{O}_{4} \mathrm{I}$, and $\mathrm{C}_{7} \mathrm{H}_{5} \mathrm{O}_{2} \mathrm{I}$. The $\mathrm{CHONI}$ formulas with three to five $\mathrm{O}$ atoms detected in ESI- mode are iodinated nitrophenol, nitronaphthol, or nitrobenzoic acid. $\mathrm{CHONI}$ formulas with one $\mathrm{O}$ atom detected in ESI+ mode are iodinated hydroxyaniline, pyridi- 
nol, or quinolinol. The most frequently detected CHONI compounds are $\mathrm{C}_{6} \mathrm{H}_{4} \mathrm{NO}_{4} \mathrm{I}, \mathrm{C}_{10} \mathrm{H}_{6} \mathrm{NO}_{3} \mathrm{I}$, and $\mathrm{C}_{6} \mathrm{H}_{4} \mathrm{NO}_{3} \mathrm{I}$. The CHNI formulas are heterocyclic amines (i.e., pyrazoles, imidazoles, and triazoles), among which $\mathrm{C}_{7} \mathrm{H}_{11} \mathrm{~N}_{2} \mathrm{I}$ was detected in 4 out of 10 samples.

Further assignment of the exact identity for the above formulas is impractical, because these 35 molecular formulas probably stand for hundreds of isomers for most of which no commercial standards are available. Nevertheless, the identities of four compounds have been confirmed including iodoacetic acid $\left(\mathrm{C}_{2} \mathrm{H}_{3} \mathrm{O}_{2} \mathrm{I}\right)$, 3-iodo-2-propenoic acid $\left(\mathrm{C}_{3} \mathrm{H}_{3} \mathrm{O}_{2} \mathrm{I}\right)$, 3-iodo-benzoic acid $\left(\mathrm{C}_{7} \mathrm{H}_{5} \mathrm{O}_{2} \mathrm{I}\right)$, and 2-hydroxy5-iodopyridine $\left(\mathrm{C}_{5} \mathrm{H}_{4} \mathrm{NOI}\right)$ according to the retention times of their commercial standards. These 4 compounds are identifiable because they have no or very few isomers, of which the commercial standards can be procured. Subsequently, these four compounds can be used as surrogate standards to semi-quantify the concentrations of other organic iodine species.

\subsubsection{Inorganic iodine species}

In addition to the above organic iodine compounds, some inorganic iodine species were also detected. Figure 6 shows the integrated mass spectrum of molecular ions between RT 0.5 and 0.7 min obtained by low-energy MS scan of an S13 nanoMOUDI sample (10-18 nm particles) collected during the INPF days. The most abundant species is $\mathrm{IO}_{3}^{-}$, followed by $\mathrm{I}^{-}$and $\mathrm{HSO}_{4}^{-}$. The $\mathrm{I}_{3}^{-}$was also observed, probably due to the adduct formation between $\mathrm{I}^{-}$and $\mathrm{I}_{2} . \mathrm{IO}_{2}^{-}$and $\mathrm{IO}^{-}$are detectable, but their abundances are 2 orders of magnitude lower than $\mathrm{IO}_{3}^{-}$. Iodine oxides $\mathrm{I}_{2} \mathrm{O}_{2-5}$ were not ionizable by the ESI source, but they might have been hydrated to $\mathrm{HIO}_{x}$ and detected as $\mathrm{IO}_{x}^{-}$(Sipilä et al., 2016). Iodide-metal complexes like $\mathrm{CuI}_{2}^{-}, \mathrm{Cu}_{2} \mathrm{I}_{3}^{-}, \mathrm{ZnI}_{3}^{-}$, and $\mathrm{CuI}_{2}(\mathrm{HCN})(\mathrm{HCl})^{-}$were observed in $\mathrm{PM}_{2.5}$ samples but not in size-segregated nanoMOUDI samples. $\mathrm{Cu}^{+}$and $\mathrm{Zn}^{2+}$ are typical coarse mode components. The observation thus indicated that the iodidemetal complexes detected in the $\mathrm{PM}_{2.5}$ samples were formed only after fine- and coarse-mode components were mixed in the sample extract. To avoid artificial formation of iodidemetal complexes during the sample extraction process, our result highlights the importance of collecting $\mathrm{PM}_{0.5}, \mathrm{PM}_{1}$ or size-segregated samples instead of $\mathrm{PM}_{2.5}$ or $\mathrm{PM}_{10}$.

\subsubsection{Semi-quantification of identified iodine species}

So far 35 organic iodine formulas ( 45 isomer peaks) and 5 inorganic iodine anions have been identified. In order to know their size distributions and relative abundances in different types of samples, the following strategy was applied to semiquantify these iodine species (step 4, Fig. 4): external calibration curves of peak area vs. concentration were established by analyzing standard solutions of $\mathrm{KI}, \mathrm{KIO}_{3}$, iodoacetic acid, 3-iodo-2-propenoic acid, 3-iodo-benzoic acid and 2-

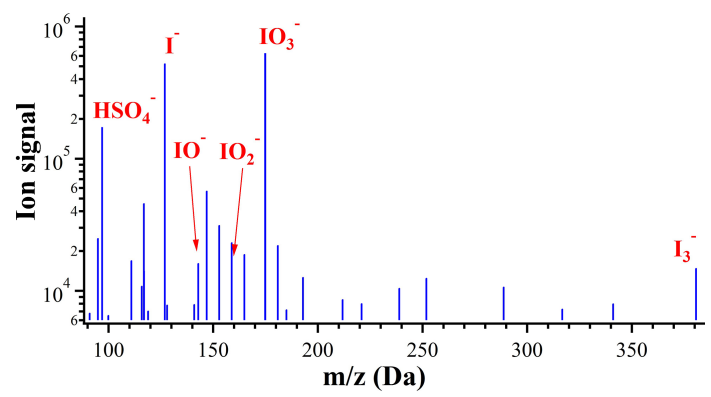

Figure 6. Integrated mass spectrum of molecular ions between retention time $0.5-0.7 \mathrm{~min}$ of an S13 nano-MOUDI sample (10$18 \mathrm{~nm}$ particles). Units (Da) are in dalton.

hydroxy-5-iodopyridine. $\mathrm{I}^{-}, \mathrm{I}_{3}^{-}$and iodide-organic adducts were quantified using $\mathrm{KI}$ as a surrogate standard by assuming their ionization efficiencies are similar in ESImode. The peak area of iodide-organic adducts was calculated as the total peak area of extracted ion chromatogram of $m / z 126.9039$ after RT 1 min. Iodide-metal complexes like $\mathrm{CuI}_{2}^{-}, \mathrm{Cu}_{2} \mathrm{I}_{3}^{-}, \mathrm{ZnI}_{3}^{-}$and $\mathrm{CuI}_{2}(\mathrm{HCN})(\mathrm{HCl})^{-}$, if present, were also quantified using $\mathrm{KI}$ but counted as $\mathrm{I}^{-}$. $\mathrm{IO}_{3}^{-}, \mathrm{IO}_{2}^{-}$ and $\mathrm{IO}^{-}$were quantified using $\mathrm{KIO}_{3}$ by assuming iodate, iodite, and hypoiodite have similar ionization efficiencies. Iodoacetic acid and 3-iodo-2-propenoic acid were quantified with their respective standards. The other three non-aromatic compounds diiodoacetic acid, iodo-methanesulfonic acid, and diiodomethane were quantified using surrogate standard iodoacetic acid. All $\mathrm{CHO}$ and $\mathrm{CHNO}$ compounds observed in ESI- mode were quantified using 3-iodo-benzoic acid, because they have a similar structure to a carboxyl or phenol group attached to aromatic rings. All CHNO and CHN compounds observed in ESI+ mode were quantified with 2hydroxy-5-iodopyridine by assuming these aromatic or heterocyclic amines have similar ionization efficiencies. Due to the small amounts of individual aromatic compounds, a total concentration of all aromatic iodine compounds detected was presented for each sample. Field blank filters were processed in the same way as sample filters. No signals above MS background were detected in the field blank filters for the iodine species other than $\mathrm{I}^{-}$and $\mathrm{IO}_{3}^{-}$. The MS signals of $\mathrm{I}^{-}$and $\mathrm{IO}_{3}^{-}$in the field blanks were comparable to those in the sample filters without iodine loading (e.g., the nanoMOUDI filters in the size bins larger than nucleation mode during the I-NPF days), but less than $1.3 \%$ of those in the sample filters with iodine loading. The MS signals of $\mathrm{I}^{-}$and $\mathrm{IO}_{3}^{-}$in the field blank were then subtracted from the aerosol samples.

There are a few limitations in the abovementioned strategy. First, the use of surrogate standards can only be regarded as semi-quantification for unassigned species. Second, it is still possible that some unknown organic iodine compounds are missed by our method shown in Fig. 4. Third, inorganic iodine ions that elute around $0.5-0.7 \mathrm{~min}$ are prone 


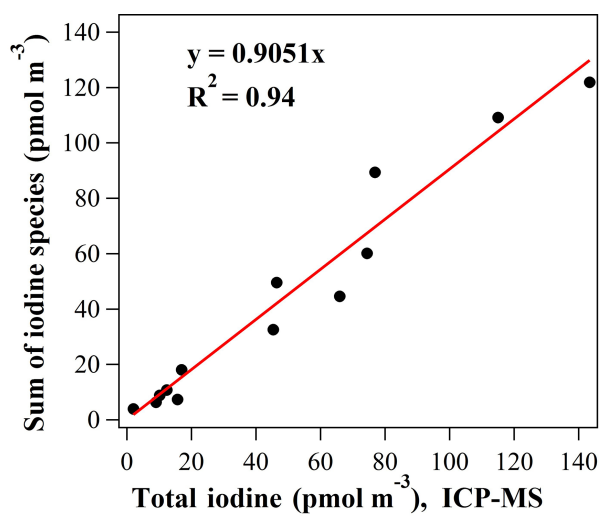

Figure 7. A comparison between the sum of all iodine species measured by our method and total iodine concentration measured by ICP-MS. Red line shows the linear regression between the two methods with a $R^{2}$ of 0.94 .

to a stronger matrix ion suppression effect than organic compounds. The underestimation may be the most serious if there are high concentrations of co-eluting sulfate, nitrate, and ammonium in the aerosol samples of accumulation mode. After UPLC/Q-TOF-MS measurement, we selected 13 samples with relatively high iodine concentrations for ICP-MS analysis, including $3 \mathrm{PM}_{2.5}$ samples and 10 size-segregated samples from $10 \mathrm{~nm}$ to $1.8 \mu \mathrm{m}$ collected during the NPF days. A linear regression analysis was conducted between the sum of all iodine species measured by this method and the total iodine measured by ICP-MS. As shown in Fig. 7, the total iodine concentration analyzed by our method is $90.5 \%$ on average of that obtained by ICP-MS with a $R^{2}$ of 0.94 . In spite of the above uncertainties, our method provided a lower-limit estimate of iodine concentrations in ambient aerosols.

\subsection{Concentration and size distribution of iodine species during the NPF days at the coastal site}

We compared the total concentrations (Fig. 8) and mass size distributions (Fig. 9) of iodine species in $10 \mathrm{~nm}-18 \mu \mathrm{m}$ particles during the I-NPF, continental NPF, and non-NPF days at the coastal site. The particle number size distributions during the same NPF days have been shown in Fig. 2. It should be noted that, identical to previous aerosol iodine speciation studies, the concentration reported here $\left(\mathrm{pmol} \mathrm{m}^{-3}\right)$ is an average over the entire period of 3 sampling days. Thus, iodine concentrations during the intense NPF periods should be higher than the values reported in this work. Continuous mass size distribution was fitted from the measured sizesegregated mass concentration data by assuming multimodal lognormal size distributions (Yu et al., 2010). Size distribution of sulfate $\left(\mathrm{HSO}_{4}^{-}\right)$was also shown $\left(\mu \mathrm{g} \mathrm{m}^{-3}\right)$ in Fig. 9. Although not highly accurate, the relative distribution in different sizes is less affected by the uncertainties of semiquantification.

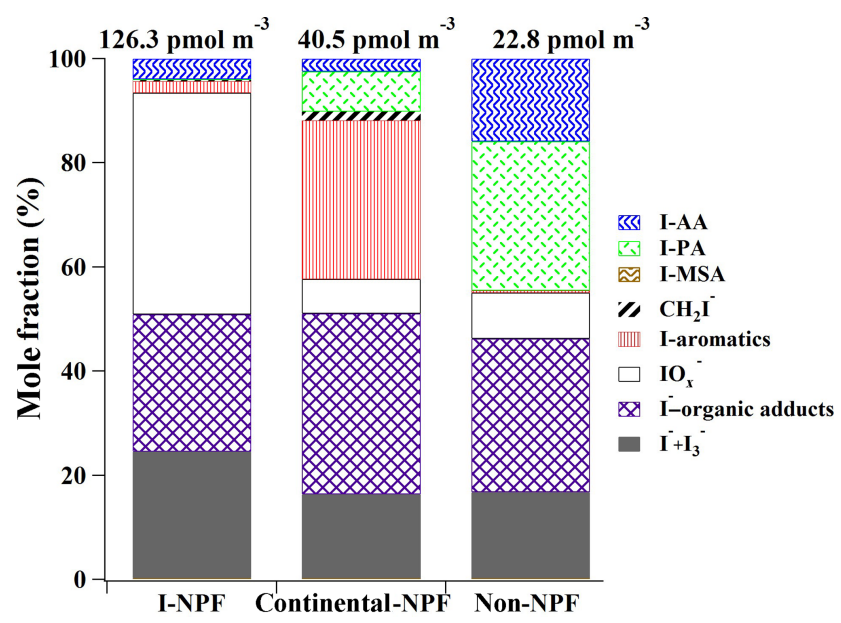

Figure 8. Total concentrations and mole fractions of iodine species in $10 \mathrm{~nm}-18 \mu \mathrm{m}$ particles during the iodineinduced NPF (I-NPF), continental NPF, and non-NPF days. I-AA: the sum of iodoacetic acid and diiodoacetic acid; IPA: iodopropenoic acid; I-MSA: iodomethanesulfonic acid; $\mathrm{CHI}_{2}^{-}$: diiodomethane; I-aromatics: total aromatic iodine compounds; $\mathrm{IO}_{x}^{-}:\left[\mathrm{IO}_{3}^{-}\right]+\left[\mathrm{IO}_{2}^{-}\right]+\left[\mathrm{IO}^{-}\right] ; \mathrm{I}^{-}$-organic adducts: iodideorganic adducts; $\mathrm{I}^{-}+\mathrm{I}_{3}^{-}$: the sum of iodide and triiodide.

The highest total iodine concentration $126.3 \mathrm{pmol} \mathrm{m}^{-3}$ was found during the I-NPF days, which was 3.1 and 5.5 times higher than those during the continental NPF and non-NPF events, respectively. As shown in Fig. 9a, all iodine species except iodoacetic acid were characterized by a nucleation mode with mode diameters between 22 and $35 \mathrm{~nm}$ during the I-NPF days. This clearly shows that iodine was the NPF precursor in this type of NPF events. The most remarkable iodine species during the I-NPF days is $\mathrm{IO}_{3}^{-}$with a mole fraction of $42.5 \%$. This is consistent with the recent observation that $\mathrm{HIO}_{3}$ is the key nucleating precursor in INPF events (Sipilä et al., 2016). On the other hand, the sum of iodide $\left(\left[\mathrm{I}^{-}\right]+\left[\mathrm{I}_{3}^{-}\right]\right)$and iodide-organic adducts accounted for $\sim 50 \%$ of total iodine in newly formed iodine particles. The presence of high iodide concentration in clusters or new particles has not been reported by previous field or laboratory measurements using CI-Api-TOF (chemical ionization with atmospheric pressure interface time-of-flight) or AMS (O'Dowd et al., 2002b; Mcfiggans et al., 2004; Sipilä et al., 2016). Iodide is most likely originating from the partitioning of gaseous precursor $\mathrm{HI}$ formed during the photolysis of $\mathrm{I}_{2}$ or iodomethane. HI itself is not a good nucleation precursor due to the lack of $\mathrm{H}$ bond or halogen bond, but our measurement suggests that $\mathrm{HI}$ might contribute to new particle growth in the size range as small as $10-18 \mathrm{~nm}$. The finding of $\mathrm{HSO}_{4}^{-}$in nucleation mode (Figs. 6 and 9a) indicates that $\mathrm{H}_{2} \mathrm{SO}_{4}$ also contributed to new particle growth during the I-NPF days. This is consistent with previous laboratory observations of 
(a) I-NPF

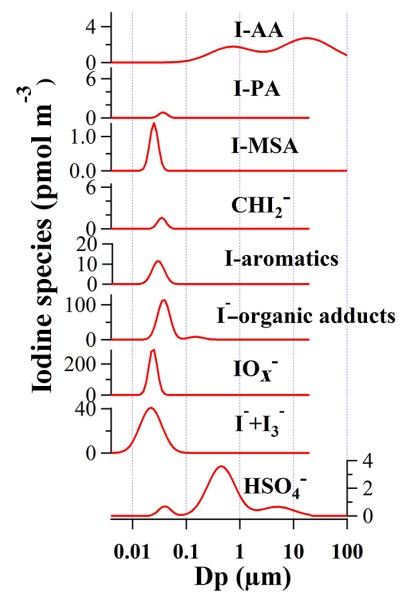

(b) Continental NPF

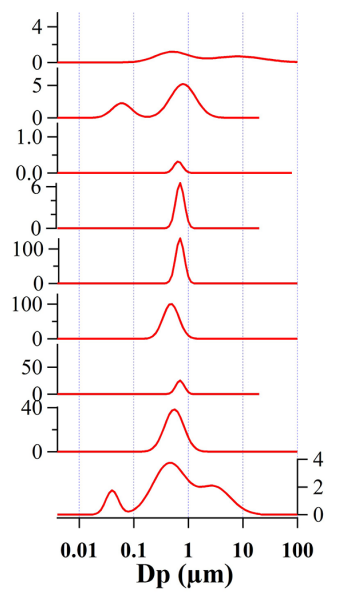

(c) Non-NPF

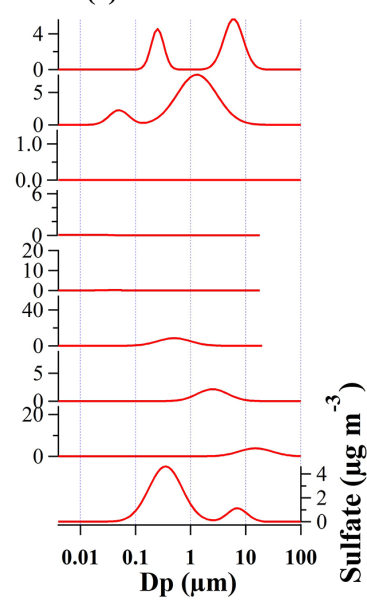

Figure 9. Mass size distribution of iodine species in $10 \mathrm{~nm}-18 \mu \mathrm{m}$ particles during (a) iodine-induced NPF (I-NPF) days, (b) continental NPF days, and (c) non-NPF days. Continuous size distributions of iodine species were inverted from the measured mass concentrations in the 13 size bins of nano-MOUDI. $Y$ axis is shown as $\mathrm{d} C / \mathrm{d} \log D_{p}$. I-AA: the sum of iodoacetic acid and diiodoacetic acid; IPA: iodopropenoic acid; I-MSA: iodomethanesulfonic acid; $\mathrm{CHI}_{2}^{-}$: diiodomethane; I-aromatics: total aromatic iodine compounds; $\mathrm{IO}_{x}^{-}$: $\left[\mathrm{IO}_{3}^{-}\right]+\left[\mathrm{IO}_{2}^{-}\right]+\left[\mathrm{IO}^{-}\right] ; \mathrm{I}^{-}$-organic adducts: iodide-organic adducts; $\mathrm{I}^{-}+\mathrm{I}_{3}^{-}$: the sum of iodide and triiodide.

efficient uptake of $\mathrm{H}_{2} \mathrm{SO}_{4}$ onto humidified iodine oxide particles below $20 \mathrm{~nm}$ (Saunders et al., 2010).

Although organic iodine compounds were most frequently found in the I-NPF samples (Table 1), they accounted for only $6.8 \%$ of total iodine in the newly formed iodine particles. Considering the short lifetime of new particles in the atmosphere, organic iodine compounds were most likely from the heterogeneous uptake of gaseous HOI (formation route: $\mathrm{I} \cdot \rightarrow \mathrm{IO} \cdot \rightarrow \mathrm{HOI}$ ) and subsequent reactions with organics in the new particles. One exception is iodoacetic acid that was characterized by a smaller accumulation mode and a larger coarse mode. Backward trajectory analysis showed that air masses moved from the open ocean of the East China Sea during the I-NPF days (Fig. S2). The unique size distribution of iodoacetic acid indicates that direct sea salt emission was probably its major source.

Lower iodine concentrations during the continental NPF days and non-NPF days might be due to the relatively low iodine emission rate or transformation rate (from gaseous emission to particles) in non-algae-growth season or cloudy days. Iodine during the continental NPF days was characterized by an accumulation mode with mode diameters between 500 and $700 \mathrm{~nm}$ (Fig. 9b), except that iodoacetic acid had a coarse mode and 3-iodo-2-propenoic acid had a $60 \mathrm{~nm}$ Aitken mode. The absence of nucleation mode for most iodine compounds implies that iodine was unlikely to be an important NPF precursor in the continental NPF. Despite different size distribution from I-NPF, the mole fraction of iodide and iodideorganic adducts were again $\sim 50 \%$ of total iodine during the continental NPF. The outstanding species in the continental NPF days were aromatic iodine compounds that accounted for $30 \%$ of total iodine. This is not surprising because air masses from inland areas of China on these days might contain a large amount of anthropogenic aromatic substances. Upon arrival in the coastal region, the uptake of gaseous HI, $\mathrm{HOI}$, or $\mathrm{IONO}_{2}$ onto these anthropogenic particles and the subsequent aerosol phase reactions between $\mathrm{I}^{-}, \mathrm{H}_{2} \mathrm{O}_{2} / \mathrm{O}_{3}$, $\mathrm{HOI}$, and aromatic compounds are hypothesized to be the formation mechanism of aromatic iodine compounds.

Iodoacetic acid and 3-iodo-2-propenoic acid surprisingly accounted for $44.3 \%$ of total iodine concentration $\left(22.8 \mathrm{pmol} \mathrm{m}^{-3}\right)$ during the non-NPF days. The high iodoacetic acid concentration, together with its presence in coarse mode, again suggests its unique source associated with sea salt emission. The compound 3-iodo-2-propenoic acid during the non-NPF days and continental NPF days was characterized by a bimodal distribution with mode diameters around $1 \mu \mathrm{m}$ and $50-63 \mathrm{~nm}$. In contrast, the bimodal distribution was replaced by a single small nucleation mode during the I-NPF days. The sources of 3-iodo-2-propenoic acid and iodoacetic acid became more important during the non-NPF days and merit more investigation.

\subsection{Comparison between coastal site and inland site}

Table 2 gives a comparative overview of iodine species in $\mathrm{PM}_{2.5}$ between the inland urban site and the coastal site. The coastal samples include the three sets of nano-MOUDI data presented in Fig. 8, from which the concentrations of various iodine species in $10 \mathrm{~nm}-3.2 \mu \mathrm{m}$ particles were extracted to approximate $\mathrm{PM}_{2.5}$; the rest of the data were acquired by directly analyzing the $\mathrm{PM}_{2.5}$ samples. It is found that total iodine was in the range of $6.5-11.2$ and $19.5-122.6 \mathrm{pmol} \mathrm{m}^{-3}$ at the inland and coastal sites, respectively. Larger variation 
Table 1. Organic iodine compounds that were detected at least once in the aerosol samples ( $n$ is the number of samples). Four PM 2.5 samples were collected at the inland site; three $\mathrm{PM}_{2.5}$ samples and three sets of nano-MOUDI samples were collected at the coastal site. $m / n$ numbers in right 4 columns: a given molecular formula was detected in $m$ out of $n$ samples. A blank cell means the formula was not detected in any samples. Also shown are measured ion mass, exact ion mass, and the number of isomers based on the number of chromatographic peaks observed for given ion mass in the samples. Bold formulas are observed in ESI+ mode and others in ESI- mode.

\begin{tabular}{|c|c|c|c|c|c|c|c|c|}
\hline \multirow{2}{*}{$\begin{array}{l}\text { Molecular } \\
\text { formula }\end{array}$} & \multirow{2}{*}{$\begin{array}{l}\text { Measured } \\
\text { ion mass } \\
\text { (Da) }\end{array}$} & \multirow{2}{*}{$\begin{array}{l}\text { Exact } \\
\text { ion mass } \\
\text { (Da) }\end{array}$} & \multirow{2}{*}{$\begin{array}{l}\text { Isomer } \\
\text { number }\end{array}$} & \multicolumn{3}{|c|}{ Coastal site $(n=6)$} & \multirow{2}{*}{$\begin{array}{l}\text { Inland } \\
\text { site } \\
(n=4)\end{array}$} & \multirow{2}{*}{$\begin{array}{c}\text { All } \\
\text { samples }\end{array}$} \\
\hline & & & & I-NPF & $\begin{array}{c}\text { Continental } \\
\text { NPF }\end{array}$ & $\begin{array}{l}\text { Non- } \\
\text { NPF }\end{array}$ & & \\
\hline $\mathrm{C}_{2} \mathrm{H}_{3} \mathrm{O}_{2} \mathrm{I}$ & 184.9099 & 184.9099 & 1 & $3 / 4$ & $1 / 1$ & $1 / 1$ & $4 / 4$ & $9 / 10$ \\
\hline $\mathrm{C}_{3} \mathrm{H}_{3} \mathrm{O}_{2} \mathrm{I}$ & 196.9098 & 196.9099 & 1 & $4 / 4$ & $1 / 1$ & & $1 / 4$ & $6 / 10$ \\
\hline $\mathrm{CH}_{2} \mathrm{I}_{2}$ & 266.8177 & 266.8168 & 1 & $3 / 4$ & $1 / 1$ & & $1 / 4$ & $5 / 10$ \\
\hline $\mathrm{C}_{2} \mathrm{H}_{2} \mathrm{O}_{2} \mathrm{I}_{2}$ & 310.8079 & 310.8066 & 1 & $4 / 4$ & & & & $4 / 10$ \\
\hline $\mathrm{CH}_{2} \mathrm{SO}_{3} \mathrm{I}_{2}$ & 346.7743 & 346.7736 & 1 & $2 / 4$ & $1 / 1$ & & & $3 / 10$ \\
\hline $\mathrm{C}_{6} \mathrm{H}_{4} \mathrm{NO}_{4} \mathrm{I}$ & 279.9112 & 279.9107 & 1 & $3 / 4$ & $1 / 1$ & $1 / 1$ & $4 / 4$ & $9 / 10$ \\
\hline $\mathrm{C}_{10} \mathrm{H}_{6} \mathrm{NO}_{3} \mathrm{I}$ & 313.9319 & 313.9314 & 1 & $4 / 4$ & $1 / 1$ & $1 / 1$ & $3 / 4$ & $9 / 10$ \\
\hline $\mathrm{C}_{6} \mathrm{H}_{4} \mathrm{NO}_{3} \mathrm{I}$ & 263.9164 & 263.9158 & 1 & $4 / 4$ & $1 / 1$ & $1 / 1$ & $2 / 4$ & $8 / 10$ \\
\hline $\mathrm{C}_{7} \mathrm{H}_{6} \mathrm{NO}_{4} \mathrm{I}$ & 293.9269 & 293.9263 & 2 & $3 / 4$ & $1 / 1$ & & & $4 / 10$ \\
\hline $\mathrm{C}_{5} \mathrm{H}_{4} \mathrm{NOI}$ & 221.9414 & 221.9416 & 2 & $3 / 4$ & & & & $3 / 10$ \\
\hline $\mathrm{C}_{6} \mathrm{H}_{6} \mathrm{NOI}$ & 235.9571 & 235.9572 & 2 & $3 / 4$ & & & & $3 / 10$ \\
\hline $\mathrm{C}_{7} \mathrm{H}_{8} \mathrm{NOI}$ & 249.9726 & 249.9729 & 3 & $3 / 4$ & & & & $3 / 10$ \\
\hline $\mathrm{C}_{9} \mathrm{H}_{10} \mathrm{NO}_{4} \mathrm{I}$ & 321.9572 & 321.9576 & 2 & $1 / 4$ & $1 / 1$ & & $1 / 4$ & $3 / 10$ \\
\hline $\mathrm{C}_{8} \mathrm{H}_{6} \mathrm{NO}_{5} \mathrm{I}$ & 321.9216 & 321.9212 & 1 & $2 / 4$ & & & & $2 / 10$ \\
\hline $\mathrm{C}_{9} \mathrm{H}_{6} \mathrm{NOI}$ & 271.9570 & 271.9572 & 2 & $2 / 4$ & & & & $2 / 10$ \\
\hline $\mathrm{C}_{8} \mathrm{H}_{8} \mathrm{NO}_{5} \mathrm{I}$ & 323.9370 & 323.9369 & 1 & $1 / 4$ & & & & $1 / 10$ \\
\hline $\mathrm{C}_{8} \mathrm{H}_{7} \mathrm{O}_{2} \mathrm{I}$ & 260.9411 & 260.9412 & 1 & $3 / 4$ & $1 / 1$ & $1 / 1$ & $2 / 4$ & $7 / 10$ \\
\hline $\mathrm{C}_{7} \mathrm{H}_{5} \mathrm{O}_{4} \mathrm{I}$ & 278.9156 & 278.9154 & 2 & $2 / 4$ & $1 / 1$ & $1 / 1$ & $2 / 4$ & $6 / 10$ \\
\hline $\mathrm{C}_{7} \mathrm{H}_{5} \mathrm{O}_{2} \mathrm{I}$ & 246.9260 & 246.9256 & 1 & $3 / 4$ & $1 / 1$ & & $1 / 4$ & $5 / 10$ \\
\hline $\mathrm{C}_{8} \mathrm{H}_{5} \mathrm{O}_{3} \mathrm{I}$ & 274.9210 & 274.9205 & 1 & & $1 / 1$ & & $2 / 4$ & $3 / 10$ \\
\hline $\mathrm{C}_{6} \mathrm{H}_{3} \mathrm{OI}_{3}$ & 470.7245 & 470.7240 & 1 & $1 / 4$ & $1 / 1$ & & & $2 / 10$ \\
\hline $\mathrm{C}_{7} \mathrm{H}_{4} \mathrm{O}_{3} \mathrm{I}_{2}$ & 388.8177 & 388.8172 & 1 & $1 / 4$ & $1 / 1$ & & & $2 / 10$ \\
\hline $\mathrm{C}_{7} \mathrm{H}_{5} \mathrm{O}_{3} \mathrm{I}$ & 262.9209 & 262.9205 & 2 & $1 / 4$ & $1 / 1$ & & & $2 / 10$ \\
\hline $\mathrm{C}_{7} \mathrm{H}_{6} \mathrm{O}_{2} \mathrm{I}_{2}$ & 374.8383 & 374.8379 & 1 & $1 / 4$ & $1 / 1$ & & & $2 / 10$ \\
\hline $\mathrm{C}_{7} \mathrm{H}_{7} \mathrm{O}_{4} \mathrm{I}$ & 280.9298 & 280.9311 & 1 & $2 / 4$ & & & & $2 / 10$ \\
\hline $\mathrm{C}_{8} \mathrm{H}_{4} \mathrm{O}_{2} \mathrm{I}_{2}$ & 372.8230 & 372.8222 & 1 & $1 / 4$ & $1 / 1$ & & & $2 / 10$ \\
\hline $\mathrm{C}_{8} \mathrm{H}_{6} \mathrm{O}_{2} \mathrm{I}_{2}$ & 386.8382 & 386.8379 & 1 & $1 / 4$ & $1 / 1$ & & & $2 / 10$ \\
\hline $\mathrm{C}_{8} \mathrm{H}_{6} \mathrm{O}_{3} \mathrm{I}_{2}$ & 402.8319 & 402.8328 & 1 & $1 / 4$ & $1 / 1$ & & & $2 / 10$ \\
\hline $\mathrm{C}_{8} \mathrm{H}_{7} \mathrm{O}_{3} \mathrm{I}$ & 276.9361 & 276.9362 & 1 & $1 / 4$ & $1 / 1$ & & & $2 / 10$ \\
\hline $\mathrm{C}_{8} \mathrm{H}_{8} \mathrm{O}_{3} \mathrm{I}_{2}$ & 404.8489 & 404.8485 & 1 & $2 / 4$ & & & & $2 / 10$ \\
\hline $\mathrm{C}_{9} \mathrm{H}_{7} \mathrm{O}_{3} \mathrm{I}$ & 288.9372 & 288.9362 & 1 & $1 / 4$ & & & & $1 / 10$ \\
\hline $\mathrm{C}_{9} \mathrm{H}_{7} \mathrm{O}_{4} \mathrm{I}$ & 304.9309 & 304.9311 & 2 & $1 / 4$ & & & & $1 / 10$ \\
\hline $\mathrm{C}_{7} \mathbf{H}_{11} \mathbf{N}_{2} \mathrm{I}$ & 251.0044 & 251.0045 & 1 & $3 / 4$ & & & $1 / 4$ & $4 / 10$ \\
\hline $\mathrm{C}_{8} \mathrm{H}_{11} \mathrm{~N}_{6} \mathrm{I}$ & 319.0172 & 319.0168 & 1 & $1 / 4$ & & & & $1 / 10$ \\
\hline $\mathbf{C}_{4} \mathbf{H}_{4} \mathbf{N}_{2} \mathbf{I}_{2}$ & 334.8547 & 334.8542 & 1 & & $1 / 1$ & & & $1 / 10$ \\
\hline
\end{tabular}

in iodine concentrations at the coastal site is due to the inclusion of both I-NPF and non-NPF samples. The concentrations of nearly all iodine species at the inland site were lower than those at the coastal site. This indicates that there were no or relatively weak iodine emission sources surrounding the inland site. Our total iodine concentrations are on the same order of magnitude as those reported at Mace Head (10$532 \mathrm{pmol} \mathrm{m}^{-3}$; Gilfedder et al., 2008), an Irish coastal site where iodine NPF has long been reported, and Regensburg, an inland site of southern Germany (15.7-61.3 $\mathrm{pmol} \mathrm{m}^{-3}$; Wimschneider and Heumann, 1995), although their maximum values are higher than ours.

A negligible amount of iodate $(1.1 \%)$ was detected in only one out of the four inland samples. In fact, the concentration of iodate was also low on the days without I-NPF events at the coastal site (on average $7 \pm 1 \%$ ). Therefore, iodate is a predominant species only in newly formed particles (Fig. 9) and its concentration might be reduced soon in the aging 
Table 2. Comparison of iodine species in $\mathrm{PM}_{2.5}$ between the inland urban site and the coastal site. Iodide: the sum of $\mathrm{I}^{-}$, $\mathrm{I}_{3}^{-}$, and $\mathrm{I}^{-}-\mathrm{metal}^{-}$ complexes (if present). $\mathrm{IO}_{x}^{-}$: the sum of $\mathrm{IO}_{3}^{-}, \mathrm{IO}_{2}^{-}$, and $\mathrm{IO}^{-}$; SOI: soluble organic iodine that is calculated as the difference between total iodine and the sum of iodide and $\mathrm{IO}_{x}^{-}$. I-AA: the sum of iodoacetic acid and diiodoacetic acid; I-PA: iodopropenoic acid; I-MSA: iodomethanesulfonic acid; $\mathrm{CHI}_{2}^{-}$: diiodomethane; I-aromatics: total aromatic iodine compounds; $\mathrm{I}^{-}$-organic adducts: iodide-organic adducts. Also shown are iodine species measured by IC-ICP-MS at Mace Head (Gilfedder et al., 2008), an Irish coastal site, and Regensburg (Wimschneider and Heumann, 1995), an inland site of southern Germany. \%: the percentages of iodine species in total iodine. ND: not detected.

\begin{tabular}{|c|c|c|c|c|c|c|c|c|}
\hline \multirow[t]{2}{*}{ Iodine species } & \multicolumn{2}{|c|}{ Inland site $(n=4)$} & \multicolumn{2}{|c|}{ Coastal site $(n=6)$} & \multicolumn{2}{|c|}{ Mace Head, Ireland } & \multicolumn{2}{|c|}{ Regensburg, Germany } \\
\hline & $\begin{array}{l}\text { Conc. } \\
\left(\mathrm{pmol} \mathrm{m}^{-3}\right)\end{array}$ & $\%$ & $\begin{array}{l}\text { Conc. } \\
\left(\mathrm{pmol} \mathrm{m}^{-3}\right)\end{array}$ & $\%$ & $\begin{array}{l}\text { Conc. } \\
\left(\mathrm{pmol} \mathrm{m}^{-3}\right)\end{array}$ & $\%$ & $\begin{array}{r}\text { Conc. } \\
\left(\mathrm{pmol} \mathrm{m}^{-3}\right)\end{array}$ & $\%$ \\
\hline Iodide & $1.0-3.7$ & $23 \pm 9$ & $3.8-74.1$ & $31 \pm 14$ & $0.3-58$ & $3.7-30$ & $3.1-7.2$ & $12-31$ \\
\hline $\mathrm{IO} x^{-}$ & ND-0.087 & $0.3 \pm 0.6$ & $1.5-53.1$ & $23 \pm 14$ & nd-15 & $0.1-7.2$ & $12.6-54.2$ & $69-88$ \\
\hline SOI & $5.4-7.5$ & $77 \pm 9$ & $14.2-66.1$ & $46 \pm 27$ & $3.7-509$ & 69-96 & & \\
\hline $\mathrm{I}^{-}$-organic adducts & $4.3-6.1$ & $64 \pm 8$ & $6.7-62.9$ & $31 \pm 16$ & & & & \\
\hline $\mathrm{CH}_{2} \mathrm{I}^{-}$ & ND-0.083 & $0.2 \pm 0.4$ & $0.036-0.74$ & $0.4 \pm 0.7$ & & & & \\
\hline I-AA & $0.054-0.25$ & $1.6 \pm 1.0$ & $0.57-2.2$ & $4.8 \pm 5.6$ & & & & \\
\hline I-MSA & ND & 0 & ND-0.28 & $0.09 \pm 0.12$ & & & & \\
\hline I-PA & ND-0.016 & $0.04 \pm 0.07$ & $0.16-5.2$ & $5.9 \pm 4.6$ & & & & \\
\hline I-aromatics & $0.76-1.2$ & $12 \pm 3$ & $0.1-12.3$ & $6.7 \pm 6.8$ & & & & \\
\hline Total iodine & \multicolumn{2}{|c|}{$6.5-11.2$} & \multicolumn{2}{|c|}{$19.5-122.6$} & \multicolumn{2}{|l|}{$10-532$} & \multicolumn{2}{|c|}{$15.7-61.3$} \\
\hline
\end{tabular}

process via reactions like $\mathrm{IO}_{3}^{-}+5 \mathrm{I}^{-}+6 \mathrm{H}^{+} \rightarrow 3 \mathrm{I}_{2}+3 \mathrm{H}_{2} \mathrm{O}$ (Pechtl et al., 2007). The mole fractions of iodide were $23 \pm 9 \%$ and $31 \pm 14 \%$ at the inland and coastal sites, respectively. Following the old definition, the iodine species other than $\mathrm{I}^{-}$and $\mathrm{IO}_{3}^{-}$were calculated as soluble organic iodine (SOI). Our finding is that newly formed iodine particles were mostly composed of inorganic $\mathrm{I}^{-}$and $\mathrm{IO}_{3}^{-}(68 \pm 20 \%$ of the total iodine), but the SOI fraction increased to account for on average $76 \pm 7 \%$ of total iodine in the aged particles. Among the SOI species, the largest fraction $64 \pm 8 \%$ was attributed to iodide-organic adducts at the inland site, followed by aromatic iodine $(12 \pm 3 \%)$ and iodoacetic acid $(1.6 \pm 1.0 \%)$. All other species were not detectable or are of negligible amounts.

Table 2 clearly shows that more information on the speciation of soluble organic iodine in the aerosol samples is provided in this study as compared to previous studies. In particular, a portion of iodine technically defined as iodideorganic adducts was reported in our study for the first time, because they cannot survive in electrospray ionization processes even in the most gentle source conditions, due to the weak bounding strength of $\mathrm{I}^{-}$with organics. I-organic adducts accounted for $64 \pm 8 \%$ in the inland urban samples and $31 \pm 16 \%$ in the coastal samples. Using the IC-ICP-MS method, this portion of iodine is likely counted towards organic iodine compounds. Our analysis shows that this portion of iodine adducts can be attributed to neither stable organic iodine compounds nor free $\mathrm{I}^{-}$ions. Under certain conditions, e.g., $\mathrm{pH}$ value, iodide-organic adducts probably release free $\mathrm{I}^{-}$ions into ambient aerosols.

\section{Conclusion}

Intense new particle formation events were observed during the algae growth and farming season at Xiangshan gulf, a coastal algaculture area of China. The high iodine concentration in nucleation mode particles measured by UPLC/Q-TOF-MS confirmed that the NPF events were induced by iodine species. This is the first study to investigate iodine-induced NPF in a place other than the coastal locations of western Europe, Tasmania, or polar regions. China contributed $58 \%$ of global cultivated seaweed production (11 million tonnes in 2010; Nayar and Bott, 2014). Iodine is likely emitted to the atmosphere and transformed to nano particles during the farming, harvesting, and processing of cultivated seaweed. Increasing algae populations due to serious eutrophication in the coastal waters of China also promotes iodine emission. Therefore, wild algae, as well as farmed algae, could be an important source of new particle formation in the coastal areas of China.

Using UPLC/Q-TOF-MS, inorganic $\mathrm{I}^{-}, \mathrm{IO}_{x}^{-}$, and $\mathrm{I}_{3}^{-}$were easily identified according to their accurate ion mass. A large portion of iodide was observed to exist as weakly bound iodide-organic adducts. A signal amplification approach was applied to look for organic iodine compounds, i.e., the compounds with a $\mathrm{C}-\mathrm{I}$ bond. For the first time, 35 molecular formulas, or 45 organic compounds according to the number of isomer peaks, were identified in ambient aerosols. Iodine species on the I-NPF days and continental NPF days were characterized by a nucleation mode and an accumulation mode, respectively. For the first time, high concentrations of $\mathrm{I}^{-}$were observed in particles as small as $10-18 \mathrm{~nm}$, suggesting gaseous HI may contribute to new particle growth 
in the I-NPF events. Iodate was a remarkable species in only newly formed particles and was reduced in the aging process. Newly formed iodine particles were mostly composed of inorganic $\mathrm{I}^{-}$and $\mathrm{IO}_{3}^{-}$, but SOI ([total iodine $]-\left[\mathrm{I}^{-}\right]-\left[\mathrm{IO}_{3}^{-}\right]$) accounted for the majority of iodine in the aged particles. Generally speaking, organic iodine compounds resided in the same particle mode as inorganic iodide. It is still not clear whether organic iodine compounds contributed to nucleation or just the growth of new particles via iodine reactions with organics. During the continental NPF days, the outstanding iodine species is aromatic iodine compounds in the accumulation mode that accounted for $30 \%$ of total iodine. Those aromatic iodine compounds were probably formed from aqueous phase reactions between $\mathrm{I}^{-}, \mathrm{H}_{2} \mathrm{O}_{2} / \mathrm{O}_{3}$, $\mathrm{HOI}$ and aromatic organic compounds during in-cloud processing. The unexpected iodoacetic acid in the coarse mode that directs sea salt emission was probably its major source.

Our study provides important information on iodine speciation, concentrations, and size distributions in the context of heavy air pollution in China's coastal areas. However, source, gas-particle partitioning, and the role of these iodine species in NPF are largely speculative. Moreover, the chemical composition and the role of iodine in cluster sizes $(1-3 \mathrm{~nm})$ are still unknown. Simultaneous measurement of gaseous iodine precursors like $\mathrm{I}_{2}, \mathrm{HI}, \mathrm{HIO}_{x}$, and $\mathrm{IO}_{x}$ using online instruments like CI-Api-TOF and DOAS (differential optical absorption spectroscopy) are needed to elucidate the above questions. On the other hand, more field measurements at multiple sites are required to determine on what spatial scale iodine NPF might be of relevance in the competition with other NPF precursors.

Data availability. For any data related to this study, please contact the corresponding author Huan Yu (yuhuan_1981@163.com).

Supplement. The supplement related to this article is available online at: https://doi.org/10.5194/acp-19-4025-2019-supplement.

Author contributions. HY and HX designed and organized the study. XH and LR conducted the field measurements. HY and LR performed the instrument experiments and data analysis. HY and LR wrote the paper. MX and JH contributed to data interpretation and paper writing.

Competing interests. The authors declare that they have no conflict of interest.

Acknowledgements. The authors would like to thank the National Key Research and Development Program of China (2016YFC0203100), the National Science Foundation of China (grant number 41675124), and the International ST Cooperation Program of China (2014DFA90780).

Review statement. This paper was edited by James Allan and reviewed by Howard K. Roscoe and two anonymous referees.

\section{References}

Allan, J. D., Williams, P. I., Najera, J., Whitehead, J. D., Flynn, M. J., Taylor, J. W., Liu, D., Darbyshire, E., Carpenter, L. J., Chance, R., Andrews, S. J., Hackenberg, S. C., and McFiggans, G.: Iodine observed in new particle formation events in the Arctic atmosphere during ACCACIA, Atmos. Chem. Phys., 15, 55995609, https://doi.org/10.5194/acp-15-5599-2015, 2015.

Baker, A. R.: Inorganic iodine speciation in tropical Atlantic aerosol, Geophys. Res. Lett., 31, 187-206, https://doi.org/10.1029/2004GL020144, 2004.

Baker, A. R.: Marine aerosol iodine chemistry: The importance of soluble organic iodine, Environ. Chem., 2, 295-298, https://doi.org/10.1071/EN05070, 2005.

Baker, A. R., Sj, C. M. P., Jickells, T. D., and Thompson, D.: Iodine concentration and availability in atmospheric aerosol, Atmos. Environ., 34, 4331-4336, https://doi.org/10.1016/s13522310(00)00208-9, 2000.

Baker, A. R., Tunnicliffe, C., and Jickells, T. D.: Iodine speciation and deposition fluxes from the marine atmosphere, J. Geophys. Res.-Atmos., 106, 28743-28749, https://doi.org/10.1029/2000JD000004, 2001.

Burkholder, J., Curtius, J., Ravishankara, A., and Lovejoy, E.: Laboratory studies of the homogeneous nucleation of iodine oxides, Atmos. Chem. Phys., 4, 19-34, https://doi.org/10.5194/acp-4-192004, 2004.

Chen, Z. L., Megharaj, M., and Naidu, R.: Speciation of iodate and iodide in seawater by non-suppressed ion chromatography with inductively coupled plasma mass spectrometry, Talanta, 72 1842-1846, https://doi.org/10.1016/j.talanta.2007.02.014, 2007.

Dai, L., Wang, H., Zhou, L., An, J., Tang, L., Lu, C., Yan, W., Liu, R., Kong, S., and Chen, M. J.: Regional and local new particle formation events observed in the Yangtze River Delta region, China: Simultaneous NPF measurementsat 2 sites, J Geophys. Res.-Atmos., 122, 2389-2402, https://doi.org/10.1002/2016JD026030, 2017.

Dall'Osto, M., Simo, R., Harrison, R. M., Beddows, D. C. S., SaizLopez, A., Lange, R.,Skov, H., Nøjgaard, J. K., Nielsen, I. E., and Massling, A.: Abiotic and biotic sources influencing spring new particle formation in North East Greenland, Atmos. Environ., 190, 126-134, https://doi.org/10.1016/j.atmosenv.2018.07.019, 2018.

Ding, G. and Zhang, X.: A picture of polar iodinated disinfection byproducts in drinking water by (UPLC/)ESI-tqMS, Environ. Sci. Technol., 43, 9287, https://doi.org/10.1021/es901821a, 2009.

Dixneuf, S., Ruth, A. A., Vaughan, S., Varma, R. M., and Orphal, J.: The time dependence of molecular iodine emission from Laminaria digitata, Atmos. Chem. Phys., 9, 823-829, https://doi.org/10.5194/acp-9-823-2009, 2009. 
Draxler, R. R. and Rolph, G. D.: HYSPLIT-hybrid single particle lagrangian integrated trajectory model 2003, NOAA Air Resources Laboratory: Silver Spring, MD, available at: http://ready. arl.noaa.gov/HYSPLIT.php (last access: 19 March 2019), 2003.

Gilfedder, B. S., Petri, M., and Beister, H.: Iodine Speciation in Rain and Snow, in: Nucl. Atmos. Aerosol, Springer, Dordrecht, 545550, https://doi.org/10.1007/978-1-4020-6475-3_108, 2007a.

Gilfedder, B. S., Petri, M., and Biester, H.: Iodine speciation in rain and snow: Implications for the atmospheric iodine sink, J. Geophys. Res.-Atmos., 112, D07301, https://doi.org/10.1029/2006JD007356, 2007b.

Gilfedder, B. S., Lai, S. C., Petri, M., Biester, H., and Hoffmann, T.: Iodine speciation in rain, snow and aerosols, Atmos. Chem. Phys., 8, 6069-6084, https://doi.org/10.5194/acp-8-6069-2008, 2008.

Grose, M. R., Cainey, J. M., McMinn, A., and Gibson, J. A. E.: Coastal marine methyl iodide source and links to new particle formation at Cape Grim during February 2006, Environ. Chem., 4, 172-177, https://doi.org/10.1071/EN07008, 2007.

Hughes, C., Malin, G., Nightingale, P. D., and Liss, P. S.: The Effect of Light Stress on the Release of Volatile Iodocarbons by Three Species of Marine Microalgae, Limnol. Oceanogr., 51, 28492854, https://doi.org/10.4319/lo.2006.51.6.2849, 2006.

Kaňa, A., Hrubá, L., Vosmanská, M., and Mestek, O.: Analysis of iodine and its species in animal tissues, Chem. Spec. Bioavailab., 27, 81-91, https://doi.org/10.1080/09542299.2015.1087160, 2015.

Kumar, M., Saiz-Lopez, A., and Francisco, J. S.: SingleMolecule Catalysis Revealed: Elucidating the Mechanistic Framework for the Formation and Growth of Atmospheric Iodine Oxide Aerosols in Gas-Phase and Aqueous Surface Environments, J. Am. Chem. Soc., 140, 14704-14716, https://doi.org/10.1021/jacs.8b07441, 2018.

Lai, S. C., Hoffmann, T., and Xie, Z. Q.: Iodine speciation in marine aerosols along a 30,000 km round-trip cruise path from Shanghai, China to Prydz Bay, Antarctica, Geophys. Res. Lett., 35, L21803, https://doi.org/10.1029/2008g1035492, 2008.

Lee, B. H., Lopez-Hilfiker, F. D., Mohr, C., Kurtén, T., Worsnop, D. R., and Thornton, J. A.: An Iodide-Adduct HighResolution Time-of-Flight Chemical-Ionization Mass Spectrometer: Application to Atmospheric Inorganic and Organic Compounds, Environ. Sci. Technol., 48, 6309-6317, https://doi.org/10.1021/es500362a, 2014.

Liu, W., Yang, H., Li, B., and Xu, S.: Determination of Bromine and Iodine Speciation in Drinking Water Using High Performance Liquid Chromatography-Inductively Coupled PlasmaMass Spectrometry, Geostand. Geoanal. Res., 35, 69-74, https://doi.org/10.1111/j.1751-908X.2010.00033.x, 2015.

Mahajan, A. S., Sorribas, M., Gómez Martín, J. C., MacDonald, S. M., Gil, M., Plane, J. M. C., and Saiz-Lopez, A.: Concurrent observations of atomic iodine, molecular iodine and ultrafine particles in a coastal environment, Atmos. Chem. Phys., 11, 25452555, https://doi.org/10.5194/acp-11-2545-2011, 2011.

Martín, J. C., Gómez Gálvez, O., Baeza-Romero, M. T., Ingham, T., Plane, J. M. C., and Blitz, M. A.: On the mechanism of iodine oxide particle formation, Phys. Chem. Chem. Phys., 15, 1561215622, https://doi.org/10.1039/c3cp51217g, 2013.

McFiggans, G., Bale, C. S. E., Ball, S. M., Beames, J. M., Bloss, W. J., Carpenter, L. J., and Gallagher, M. W.: Iodine- mediated coastal particle formation: an overview of the Reactive Halogens in the Marine Boundary Layer (RHaMBLe) Roscoff coastal study, Atmos. Chem. Phys., 10, 2975-2999, https://doi.org/10.5194/acp-10-2975-2010, 2010.

Mcfiggans, G., Coe, H., Burgess, R., Allan, J., Cubison, M., and Alfarra, M. R.: Physics Direct evidence for coastal iodine particles from Laminaria macroalgae - linkage to emissions of molecular iodine, Atmos. Chem. Phys., 4, 701-713, https://doi.org/10.5194/acp-4-701-2004, 2004.

Nayar, S. and Bott, K.: Current status of global cultivated seaweed production and markets, World Aquacult., 45, 32-37, 2014.

O'Dowd, C. D. and De Leeuw, G.: Marine aerosol production: a review of the current knowledge, Philos. T. Roy. Soc. A, 365, 1753-1774, https://doi.org/10.1098/rsta.2007.2043, 2007.

O’Dowd, C. D., Kaarle, H., Jyrki, M., Minna, V., Pasi, A., and Gerrit, D. L.: Coastal new particle formation: Environmental conditions and aerosol physicochemical characteristics during nucleation bursts, J. Geophys. Res.-Atmos., 107, PAR 12-11-PAR 1217, https://doi.org/10.1029/2000JD000206, 2002a.

O'Dowd, C. D., Jimenez, J. L., and Bahreini, R.: Marine aerosol formation from biogenic iodine emissions, Nature, 417, 632-636, https://doi.org/10.1038/nature00775, 2002b.

Palmer, C. J., Anders, T. L., Carpenter, L. J., Küpper, F. C., and Mcfiggans, G. B.: Iodine and halocarbon response of laminaria digitata to oxidative stress and links to atmospheric new particle production, Environ. Chem., 2, 282-290, https://doi.org/10.1071/EN05078, 2005.

Pechtl, S., Schmitz, G., von Glasow, R.: Modelling iodide-iodate speciation in atmospheric aerosol: Contributions of inorganic and organic iodine chemistry, Atmos. Chem. Phys., 7, 1381-1393, https://doi.org/10.5194/acp-7-1381-2007, 2007.

Redeker, K. R., Wang, N., Low, J. C., Mcmillan, A., Tyler, S. C., and Cicerone, R. J.: Emissions of methyl halides and methane from rice paddies, Science, 290, 966-969, https://doi.org/10.1126/science.290.5493.966, 2000.

Roscoe, H. K., Jones, A. E., Brough, N., Weller, R., SaizLopez, A., Mahajan, A. S., Schoenhardt, A., Burrows, J. P., and Fleming, Z. L.: Particles and iodine compounds in coastal Antarctica, J. Geophys. Res.-Atmos., 120, 7144-7156, https://doi.org/10.1002/2015JD023301, 2015.

Saiz-Lopez, A., Plane, J. M., Baker, A. R., Carpenter, L. J., Von, G. R., Martín, J. C., Mcfiggans, G., and Saunders, R. W.: Atmospheric chemistry of iodine, Chem. Rev., 112, 1773-1804, https://doi.org/10.1021/cr200029u, 2012a.

Saunders, R. W., Kumar, R., Gomez Martin, J. C., Mahajan, A. S., Murray, B. J., and Plane, J. M. C.: Studies of the Formation and Growth of Aerosol from Molecular Iodine Precursor, Zeitschrift Fur Physikalische Chemie - International Journal of Research in Physical Chemistry \& Chemical Physics, 224, 1095-1117, https://doi.org/10.1524/zpch.2010.6143, 2010.

Sellegri, K., Yoon, Y. J., Jennings, S. G., O’Dowd, C. D., Pirjola, L., and Cautenet, S.: Quantification of coastal new ultrafine particles formation from in situ and chamber measurements during the BIOFLUX campaign, Environ. Chem., 2, 260-270, https://doi.org/10.1071/EN05074, 2006.

Seto, F. Y. B. and Duce, R. A.: A laboratory study of iodine enrichment on atmospheric sea-salt particles produced by bubbles, J. Geophy. Res., 77, 5339-5349, https://doi.org/10.1029/JC077i027p05339, 1972. 
Shah, M., Wuilloud, R. G., Kannamkumarath, S. S., and Caruso, J. A.: Iodine speciation studies in commercially available seaweed by coupling different chromatographic techniques with UV and ICP-MS detection, J. Anal. Atom. Spectrom., 20, 176-182, https://doi.org/10.1039/b415756g, 2005.

Sipilä, M., Sarnela, N., Jokinen, T., Henschel, H., Junninen, H., Kontkanen, J., Richters, S., Kangasluoma, J., Franchin, A., and Peräkylä, O.: Molecular-scale evidence of aerosol particle formation via sequential addition of $\mathrm{HIO}_{3}$, Nature, 537, 532-534, https://doi.org/10.1038/nature19314, 2016.

Sive, B. C., Varner, R. K., Mao, H., Blake, D. R., Wingenter, O. W., and Talbot, R.: A large terrestrial source of methyl iodide, Geophy. Res. Lett., 34, 251-270, https://doi.org/10.1029/2007gl030528, 2007.

Wang, K. E. and Jiang, S. J.: Determination of iodine and bromine compounds by ion chromatography/dynamic reaction cell inductively coupled plasma mass spectrometry, Anal. Sci., 24, 509514, https://doi.org/10.2116/analsci.24.509, 2008.

Wei, L., Hongxia, Y., Bing, L., Dengyun, C., and Huijuan, Z.: Speciation Stabilities of Iodine in underground Water by High Performance Liquid Chromatography-Inductively Coupled Plasma Mass Spectrometry, Chinese J. Anal. Chem., 35, 571-573, https://doi.org/10.1016/s1872-2040(07)60047-4, 2007.

Wimschneider, A. and Heumann, K. G.: Iodine speciation in size fractionated atmospheric particles by isotope dilution mass spectrometry, Fresen. J. Anal. Chem., 353, 191-196, https://doi.org/10.1007/BF00322957, 1995.

Xu, S., Xie, Z., Li, B., Liu, W., Sun, L., Kang, H., Yang, H., and Zhang, P.: Iodine speciation in marine aerosols along a $15000-\mathrm{km}$ round-trip cruise path from Shanghai, China, to the Arctic Ocean, Environ. Chem., 7, 406-412, https://doi.org/10.1071/EN10048, 2010.

Yang, Y., Peng, Y., Chang, Q., Dan, C., Guo, W., and Wang, Y.: Selective Identification of Organic Iodine Compounds Using Liquid Chromatography-High Resolution Mass Spectrometry, Anal. Chem., 88, 1275, https://doi.org/10.1021/acs.analchem.5b03694, 2016.
Yoon, Y. J., O’Dowd, C. D., Jennings, S. G., and Lee, S. H.: Statistical characteristics and predictability of particle formation events at Mace Head, J. Geophy. Res., 111, D13204, https://doi.org/10.1029/2005JD006284, 2006.

Yoshida, S., Muramatsu, Y., Katou, S., and Sekimoto, H.: Determination of the chemical forms of iodine with IC-ICP-MS and its application to environmental samples, J. Radioanal Nucl. Chem., 273, 211-214, https://doi.org/10.1007/s10967007-0738-4, 2007.

Yu, H., Wu, C., Wu, D., and Yu, J. Z.: Size Distributions of Elemental Carbon and its Contribution to Light Extinction in Urban and Rural Locations in the Pearl River Delta region, China, Atmos. Chem. Phys., 10, 5107-5119, https://doi.org/10.5194/acp10-5107-2010, 2010.

Yu, H., Zhou, L., Dai, L., Shen, W., Dai, W., Zheng, J., Ma, Y., and Chen, M.: Nucleation and growth of sub-3 nm particles in the polluted urban atmosphere of a megacity in China, Atmos. Chem. Phys., 16, 2641-2657, https://doi.org/10.5194/acp16-2641-2016, 2016.

Yun, L., Peng, Y., Chang, Q., Zhu, Q., Guo, W., and Wang, Y.: Identification of Organic Iodine Compounds and their Transformation Products in Edible Iodized Salt using Liquid Chromatography-High Resolution Mass Spectrometry, J. Agr. Food Chem., 65, 5384-5389, https://doi.org/10.1021/acs.jafc.7b01759, 2017.

Zhang, W., Liu, X., Jia, X., Yi, H., Liu, X., Xie, X., Lu, J., Duan, T., and Chen, H.: Fast Speciation of Iodide and Iodate in Edible Salts and Human Urine by Short Column IC Coupled with Inductively Coupled Plasma MS, Chromatographia, 72, 10091012, https://doi.org/10.1365/s10337-010-1756-x, 2010. 